\title{
Central limit theorem for the functional of jump Markov process
}

\author{
Nguyễn Văn Hữu \\ Vương Quân Hoàng \\ Trần Minh Ngọc \\ Báo cáo \\ Hội nghị toàn quốc lần thứ III "Xác suất - Thống kê: Nghiên cứu, ứng dụng và \\ giảng dạy" (tr. 34)
}

Ba Vì, Hà Tây, ngày 12-14 tháng 05 năm 2005

Viện Toán học

Trường Đại học Khoa học tự nhiên / Đại học Quốc gia Hà Nội 


\section{Google}

This book is provided in digital form with the permission of the rightsholder as part of a Google project to make the world's books discoverable online.

$$
\text { (c) }(1) \text { () } 9
$$

This book is licensed under a Creative Commons license. By using a Creative Commons license, the rightsholder chose to give you more freedom to share or re-use the book than would otherwise be possible under copyright law.

This license allows distribution of this book with attribution but prohibits commercial use or derivative works. Terms available here: http://creativecommons.org/licenses/by-ncnd/3.0

\section{About Google Books}

Google's mission is to organize the world's information and to make it universally accessible and useful. Google Books helps readers discover the world's books while helping authors and publishers reach new audiences. You can search through the full text of this book on the web at http://books.google.com 


\title{
Hội nghị toàn quốc lần thứ III "Xác suất - Thống kê: Nghiên cứu, ứng dụng và giảng dạy"
}

\author{
Ba Vì, Hà Tây 12--14/05/2005
}

\author{
Tóm tắt báo cáo \\ $\&$ \\ Danh sách đại biểu
}




\title{
Hội nghị toàn quốc lần thứ III "Xác suất - Thống kê: Nghiên cứu, ứng dụng và giảng dạy"
}

\author{
Ba Vì, Hà Tây 12--14/05/2005
}

\author{
Tóm tắt báo cáo \\ \& \\ Danh sách đại biểu
}

Hà Nội - 2005 


\section{Hội nghị toàn quốc lần thứ III "Xác suất - Thống kê: Nghiên cứu, ứng dụng và̀ giăng dạy"}

Ba Vi, Hà Tây 12--14/05/2005

\section{Tóm tắt báo cáo \& Danh sách đại biểu}




\section{Mục lục}

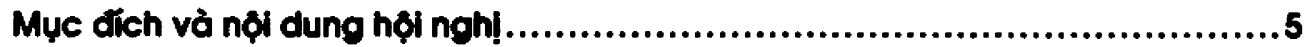

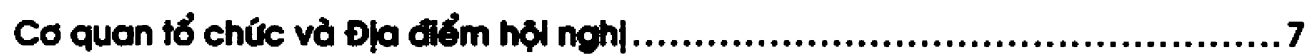

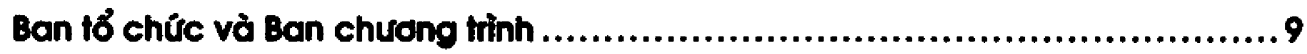

Các don vị tài trộ........................................................................

Danh mục cóc bóo cóó............................................................13

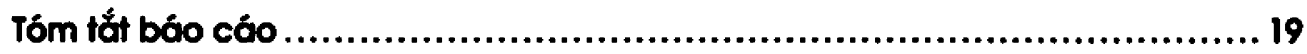

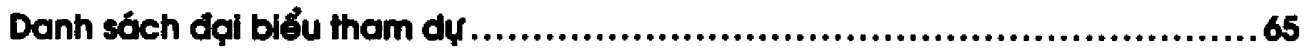

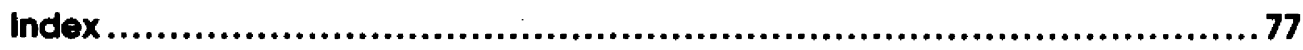




\section{Mục đích và nội dung hội nghị}

Viện Toán học cùng với Trường Đại học Khoa học Tự nhiên - Đại học Quớc gia Hà Nội tổ chức Hội nghị toàn quớc lần thứ ba "Xác suất - Thống kê: nghiên cứu, ứng dụng và giảng dạy" tại $\mathrm{Ba} V \mathrm{~V}$ - Hà Tây từ ngày 12 đến 14/5/2005. Đây là sinh hoạt khoa học quy mô toàn quốc của các nhà khoa học làm về nghiên cứu, ứng dụng và giảng dạy xác suất thống kê, tiếp tục truyền thống của hội nghị toàn quốc lần thứ nhắt tổ chức ở Nha Trang năm 1983 và lần thứ hai tổ chức ở Hà Tay năm 2001. Đè tài trọng điểm về xác suất thống kê thuộc Chương trình nghiên cứu cơ bản cấp Nhà nước sẽ chịu trách nhiệm chính về chương trình và tài chính của hội nghị.

Hội nghị là diễn đàn để các nhà khoa học trong ngành trình bày những kết quả nghiên cứu, ứng dụng và giảng dạy của mình trong thời gian qua. Các cán bợ trẻ và nghiên cứu sinh, học viên cao học và sinh viên sẽ có điều kiện tìm hiểu về tình hình hoạt động khoa học của hướng nghiên cứu trọng điểm này ở nước ta, cũng như gặp gỡ trao đởi với các thày và với thế hệ đi trước để nâng cao kiến thức và xác định phương hướng làm viẹcc lâu dài của mình. Ban tổ chức sẽ mời các chuyên gia có uy tín trong lĩnh vực xác suất thớng kê tham gia hội nghị và đọc báo cáo. Mọi cán bộ khoa học trong ngành (kể cả sinh viên, học viên cao học và nghiên cứu sinh) đều có thẻ đăng ký tham dự. 


\section{Cơ quan tổ chức và địa điểm hội nghị}

\section{Cơ quan tổ chức}

- Viện Toán học, Viện Khoa học và Công nghệ Việt Nam

- Đại học Khoa học tự nhiên - Đại học Quớc gia Hà Nọi

\section{Địa điểm hội nghị}

Trung tâm thực nghiệm giáo dục sinh thái và môi trường $\mathrm{Ba} V i ̂$ - Đại học Quớc gia Hà Nọi.

Xã Tản Lĩnh, huyện Ba Vì, Tỉnh Hà Tay.

Đ̣̣a chỉ liôn hộ:

PGS.TSKH Nguyẽn Đình Cong

Viện Toán học

18 Hoàng Quớc Việt

Câu Giáy, Hà Nọi

10307 Hà Nội

Phone: (04) 7563474 (ext.: 203)

Fax: $(+84)(4) 7564303$

E-mail: ndcong@math.ac.vn
PGS.TSKH Đặng Hùng Thắng

Khoa Toán-Cơ-Tin học

Trường ĐHKHTN - ĐHQGHN

334 Nguyễn Trãi, Thanh Xuân

Hà Nội

Phone: 0913349968

Fax:

E-mall: hungthang@hn.vnn.vn

Dịa chi Website:

http://www.math.ac.vn/conference/xstk05/ 


\section{Ban tổ chức và Ban chương trình}

\section{Ban Tổ chức}

To Văn Ban (Học viện Kỹ thuật Quân sự) Nguyễn Đình Công (Trương ban, Viện Toán học)

To Anh Düng (ĐHKHTN - ĐHQG TPHCM)

Dương Tón Dảm (ĐHQG Thành phố HCM)

Trần Lợc Hùng (Đại học Khoa học Huê)

Trần Văn Nhung (Bộ Giáo dục và Đào tạo)

Hồ Đăng Phúc (Thu ký, Viện Toán học)

Nguyễn Văn Quảng (Đại học Vinh)

Trần Văn Thành (Viện Toán học)

Đặng Hùng Thắng (Dớng trương ban, ĐHKHTN - ĐHQG Hà Nọi)

Đào Quang Tuyơn (Viện Toán học)

Vũ Viết Yôn (Đại học Sư phạm Hà Nọi)

\section{Ban chương trình}

Nguyễn Đình Công (Viện Toán học)

Nguyễn Hữu Dư (ĐHKHTN - ĐHQG Hà Nội)

Nguyễn Văn Hữu (ĐHKHTN - ĐHQG Hà Nội)

Nguyễn Quý Hỷ (ĐHKHTN - ĐHQG Hà Nội)

Đinh Quang Lưu (Viện Toán học)

Tớng Đình Quỳ (Đại học Bách khoa Hà Nọii)

Đặng Hùng Thŏ́ng (ĐHKHTN - ĐHQG Hà Nợi)

Trần Hùng Thao (Viện Toán học)

Nguyển Văn Thu (Đóng truớng ban, Viện Toán học)

Nguyễn Duy Tiến (Đồng trương ban, ĐHKHTN - ĐHQG Hà Nội)

Trần Mạnh Tuấn (Viện Khoa học và Công nghệ Việt Nam)

Nguyển Bác Vŏn (ĐHKHTN - ĐHQG TPHCM) 


\section{Các đơn vị tài trợ}

- Viện Toán học, Viện Khoa học và Công nghẹ Việt Nam

- Viện Khoa học và Cong nghệ Việt Nam

- Đại học Khoa học tự nhiên - Đại học Quớc gia Hà Nọi

- Đề tài trọng điểm "Một số vấn đề chọn lọc của Xác suất thống kê"

- Đại học Vinh

- Chương trình nghiên cứu cơ bản quốc gia, Hội đồng ngành Toán học

- TS Nguyễn Kỳ Nam, Senior Lecturer, School of Mathematics, Statistics and Computer Science, University of New England, Armidale NSW 2351 Australia.

- TS Vương Quân Hoàng, Công ty EMISCOM. 


\section{Các báo cáo chính}

- To Văn Ban (Học Viện Kỹ thuật Quân sự) Một só úng dưng cưa Thóng kê toán trong khoa học kìy thuợt và cóc giái pháp kỹ thuợt lliên quan

- Dương Tón Đảm và Dương Ngọc Hảo (Đại học Sư phạm Kỹ thuật Thành phó Hố Chí Minh) Summary of stable random process

- Tó Anh Dũng (Đại học Khoa học tự nhiên - Đại học Quớc gia Thành phố Hớ Chí Minh) Phấn tích liến tiếp

- Nguyễn Văn Hữu (Đại học Khoa học tự nhiên - Đại học Quốc gia Hà Nội), Vương Quân Hoàng (Công ty EMISCOM) và Trần Minh Ngọc (Đại học Khoa học tự nhiên - Đại học Quốc gia Hà Nội) Định lý giới hạn trung tớm cho phiếm hàm của quá trình Markov buớc nháy

- Nguyênn Hữu Du (Đại học Khoa học tự nhiên - Đại học Quớc gia Hà Nọi) Dynamics of Random and Stochastic populations

- Trần Lợc Hùng (Đại học Khoa học Huê) On a probability metric based on trotter operator and some applications in theory of limit theorems

- Nguyễn Thành Long (Uỷ ban Chứng khoán Nhà Nước) Review of efficient partial hedging

- Đinh Quang Lưu (Viện Toán học) Chợt cớt yếu và sụ hộl tụ của các trò chai véc to cóng bớng dớn theo thời gian

- Hờ Đăng Phúc (Viện Toán lọ̣c) Một sơ úng dung cưa Thớng kẻ Toán trong Y học và diéu tra xằ hợi học tại Việt Nam

- Nguyễn Văn Quáng và Lé Văn Thành (Đại học Vinh) Một só dịnh lý giới hạn dạng luợt só lón

- Phan Đức Thành và Phan Le Na (Đại học Vinh) Vế tính ớn định tiệm cợn với xác suớt 1 của các nghiọmm của l lóp phuơng trình sai phăn ngốu nhiên lto 
- Đắng Hùng Thắng (Đại học Khoa học tự nhiên - Đại học Quớc gia Hà Nội) Băi toán thác triến một ánh xạ ngốu nhién

- Trần Hùng Thao (Viẹn Toán học) Phuơng pháp toán học phán tích rủi ro tài chinh

- Nguyễn Duy Tiến và Phan Viết Thư (Đại học Khoa học tự nhiên - Đại học Quốc gia Hà Nội) Lịch sư các địinh lý giới hạn

- Nguyễn Văn Thu (Viện Toán học) Spectral representation of multiply selfdecomposable processes

- Kông Tụ (Đại học Bách khoa Hà Nọii) Vàlý kiến trao đới vế gláng dạy thóng kề ứng dụng cho cớc ngành kinh tế, khoa học xở hộl

- Đào Quang Tuyến (Viện Toán học) Giới thięu một gióo trình diện tủ vé Xác suất Thống kê

- Nguyễn Bác Văn (Đại học Khoa học tự nhiên - Đại học Quớc gia Thành phó Hồ Chí Minh) Vai trò của độ đo ngốu nhiên trong thớng kê

- Vũ Viết Yên (Đại học Sư phạm Hà Nội) On the convergence of two parameter multivalued pramarts and mils 


\section{Danh sách các báo cáo của hội nghị}

\section{Phan Thành An, Phan Lé Na và Ngó Quớc Chung}

Vể miến ởn định đới với tính ổn định tiệm cận với xác suất 1 của nghiệm zero của 1 lớp phương trình vi phản ngẵu nhiên lto . . . .

2. Nguyền Thế Düng và Trớn Lợc Hùng

Độ tin cậy khả năng của hệ thớng và thành phằn với khơng gian trạng thái mở rộng $\ldots \ldots \ldots \ldots \ldots$

\section{Tô Văn Ban}

Một số ứng dụng của Thống kê Toán trong Khoa học Kỹ thuật và các giải pháp kỹ thuật liên quan .

4. Tô Văn Ban

Xấp xỉ hàm bậc cao hàm mô hình theo nhóm các tham số

\section{Nguyễn Hữu Bảo}

On the stability of the characterization of the $\epsilon$-geometric composed variable

6. Phạm Xuân Bình

Vể một điểu kiện đủ luật mạnh só lớn . . . . . . . . . . . . . . . 24

7. Phạm Vãn Chüng

On the characterization of the geometric composed variables by constant regression . . . . . . . . . . . . . 25

8. Vũ Hoài Chương và Nguyễn Công Điều

Các dãy số tựa ngẫu nhiên hay là các dãy số có độ phân kỳ thắp 26

9. Tô Anh Düng

Phân tích liên tiếp . . . . . . . . . . . . . . . . . 27

10. Nguyễn Hữu Du

Dynamics of Random and Stochastic populations . . . . . . . 28

11. Dương Tôn Đám và Dương Ngọc Hảo

Summary of Stable Random Process . . . . . . . . . . . 29

12. Phạm Xuân Hà và Đinh Quang Lưu

Sự hội tụ của 1-amarts trong không gian Banach . . . . . . . . 30

13. Dặng Thanh Hải vả Nguyễn Hổng Hải

Mổ hình điếu khiến ngẫu nhiên với bước nhảy . . . . . . . . . 31

14. Nguyển Th!̣ Thuý Hồng và Trần Hùng Thao

Vể các hợp đớng Quanto trong toán tài chính . . . . . . . . . 32

\section{Trồn Lợc Hùng}

On a probability metric based on Trotter operator and some applications in theory of limit theorems . . . . . . . . . . . 33

16. Nguyē̃n Vŏn Hữu, Vương Quấn Hoàng và Trần Minh Ngọc

Central limit theorem for the functional of jump Markov process . . 34 


\section{Phạm Văn Khánh}

Mô phỏng đại lượng ngẵu nhiên và quá trình ngẵu nhiên $\ldots .35$

18. Phạm Văn Khánh

Những bài toán có nội dung thực tế trong giảng dạy Xác suất - Thớng

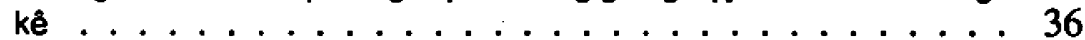

19. Lê Trung KIên, Trồn Lộc Hùng và lê Anh Vũ

Applying probabilistic model for ranking Webs in multi-context . . . 37

20. Nguyền Thònh Long

Review of Efficient Partial Hedging

21. Đinh Quang Lưu

Chật cốt yếu và sự hội tụ của các trò chơi véc tơ công bằng dần theo thời gian

22. Đinh Quang Lưu và Nguyển Thị Mỳ

Sự hội tụ của các trò chơi trong không gian Banach có tính Radon Nikodym

23. Lê Thị Xuân Mai

Không gian Gauss . . . . . . . . . . . . . . . 42

24. Hoàng Đức Mạnh

Về hai định lý cơ bản của Toán tài chính . . . . . . . . . . . . . 43

25. Đọ̆ng Thị Tố Nhu

Hàm phân tán có điều kiện . . . . . . . . . . . . . 44

26. Trần Trọng Nguyên

Phương trình Langevin phân thứ và úng dụng trong mô hình lẫi suất

27. Doãn Trần Phú và Vũ Huyền Trang

Mối liên hê giữa hai hiện tượng tự tương quan và phương sai của sai số thay đổi và qui trình khắc phục các khuyết tật của mô hình hổi qui tuyến tính cổ điển

28. Hồ Đăng Phúc

Một số ứng dụng của Thống kê Toán trong $Y$ học và điều tra xã hội học tại Việt Nam

29. Nguyễn Văn Quảng và Lê Văn Thành

Một số định lí giới hạn dạng luật số lớn

30. Nguyễn Hổ Quỳnh

Vấn để cộng tính và mô hình $\mathrm{ARCH}$

31. Đoàn Thái Sơn

Một nhận xét về tính tách được tích phân của hệ đợng lực tuyến tính không bị chặn

32. Lê Văn Thành

Luật số lớn đối với dãy hai chỉ số các phần tử ngẫu nhiên nhận giá

trị trong không gian Banach

33. Phan Đức Thành và Phan Lê Na

Vể tính ổn định tiệm cận với xác suất 1 của các nghiệm của 1 lóp phương trình sai phân ngẫu nhiên Ito

34. Trồn Hùng Thao

Phương pháp Toán học phân tích rủi ro tài chính . . . . . . . . . 54

35. Đặng Hùng Thắng

The extension of random mappings . . . . . . . . . 55

36. Nguyễn Thịnh và Đọ̆ng Hùng Thắng

Biểu diển phớ của toán tử ngẳu nhiên . . . . . . . . . . . 56 
37. Nguyễn Văn Thu

Spectral Represetation of Multiply Self-Decomposable Processes . 57

38. Nguyễn Duy Tiến và Phan Viêt Thư

Lịch sử các định lý giới hạn . . . . . . . . . . . . . . . . . 58

39. Kông Tụ

Vài ý kiến trao đổi về giảng dạy Thớng kê ứng dụng cho các ngành

kinh tế, khoa học xã hội . . . . . . . . . . . . . . . . . . . . 59

40. Đào Quang Tuyến, Hồ Đăng Phúc và Trồn Mọnh Tuón

Giới thiệu một giáo trình điện tử vể xác suất thớng kê . . . . . . . 60

41. Nguyễn Bác Văn

Vai trò của độ đo ngẫu nhiên trong thớng kê . . . . . . . . . . . . 61

42. Bùl Quang Vũ

Mó Phỏng Một Sớ Bài toán Xác Suắt đả tính sớ $\pi$. . . . . . . . . 62

43. Vũ Viết Yên

On the Convergence of two-parameter multivalued pramarts and mils 63 


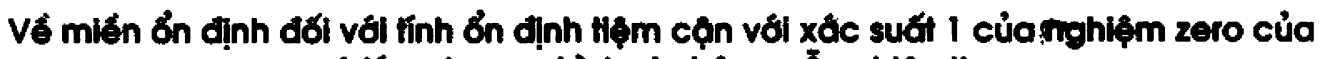
1 lóp phương trình vi phấn ngăúu nhiên lìo

Phan Thành An ${ }^{1}$, Phan Lê $\mathrm{Na}^{2}$ và $\underline{\mathrm{Ngó}}$ Quớc Chung $^{3}$

Tóm tắt: Báo cáo này trình bày một cách tìm miền tham số đối với tính ổn định với xác suất 1 của nghiệm zero của i lópp phương trình vi phân ngẫu nhiên lto tuyến tính dụa trên điểu kiện cần và đủ của Kovenevski và Mitropolski và các điếu kiện cần và đủ của chúng tôi.

1 Phan Thành An

Viên Toán học

Viện Khoa học và Công nghệ Việt Nam

18 Hoàng Quốc Việt, Cầu Giấy, Hà Nội

thanhan@math.ac.vn

2 Phan Lé Na Đai hoc Vinh

Thành Phó Vinh, Nghẹ An

phanlena@yahoo.com

3 Ngơ Qức Chung

Trung tåm Vợt lý Lý thuyét Abdus Salam.

italy 
Độ fin cộy khả năng của ḩ̣ thớng vả thành phờn vớl khớng gian trạng thái mỏ rộng

\section{Nguyễn Thé Dūng ${ }^{1}$ và Trờn Lợc Hùng ${ }^{2}$}

Tóm tắ: Trong bài này chúng tôi giới thiệu dàn đầy đủ - đại số gia tủ $L$ sinh bởi các phần tủ sinh true, false và mở rộng khái niệm $t$-chuẩn trên đó. Tù đó chỉ ra rằng các kết quả về độ tin cậy khả năng của hể thống trong [9] có thể mở rộng ra, không chi là một giá trị xác suất trên đoạn $[0,1]$ mà còn là những khái niệm mờ diễn $t$ khả năng nhu "Very true", "Little true", "More Little false"... Tiếp theo chúng tôi xây dụng khái niệm và mở rộng các kết qủa về độ tin cộy khả năng trong [9] cho các hệ thống mà không gian trạng thái của chúng không chỉ bao gồm 2 trạng thái "fail" vă "work" mà là các khái niệm mò diễn $t$ các trạng thái thường gợp trong thục tê nhu "Very good", "Possibility bad"...

1 Nguyễn Thé Dũng

Khoa Tin Đại học Su Phạm Huế

32 Lế Lợi, Thành Phố Hué

2 Trồn Lộc Hùng

Đại học Khoa học Hué

77 Nguyěn Huệ, Thành phó Huế

emai: thung@hueuni.edu.vn 

Một só úng dụng của Thóng kê Toán trong Khoa học Kȳ thuột và các giải pháp kỹ
thuột liến quan

\section{Tô Văn Ban'}

Tóm tắt: Báo cáo trình bày tổng quan một số úng dụng của thống kê trong KHKTQS. Bài toán kiểm định gia thuyết thống kê với tiêu chuẩn cực tiểu hàm thiệt hại, tiêu chuẩn Neyman - Pierson được áp dụng cho bài toàn phát hiện của ra đa; trên cơ sở đó xây dựng thuật toán quyết định tối ưu và máy thu tối ưu. Nhiều mô hinh ổn định xác suất báo động lầm được đưa ra nhằm làm tăng xác suất báo động đúng, trong đó sủ dụng phương pháp ước lượng tham số hoọ̆c phi tham số, sủ dụng thống kê hạng. Chúng tồi cũng đề nghị một lược đồ quan sát nhiều lớp nhằm giảm kích thước vùng quan sát. Một số úng dụng của thống kê trong pháo binh cunng được để cộp, bao gồm elip tán mát: phương pháp xác định độ lệch tầm, độ lệch hướng theo lí thuyết và bằng thục nghiệm; những đặc trung tán mát của đạn phản lực.

1 To Văn Ban

Học Viện Kỹ thuột Quân su

100 Hoảng Quớc Việt, Cấu Giớy Hà Nộl 
Xăp xỉ hàm bọ̣c cao hàm mó hình theo nhóm các tham sơ

Iô Văn Ban 1

Tóm tắt: Xét mổ hình hổi quy phi tuyến .

$$
y_{i}=\eta\left(x_{i}, \theta\right)+\varepsilon_{i} ; i=1,2, \ldots, n ; \theta \in \Theta C \mathbb{R}^{n}
$$

Khai triến Taylor đển bộc ba hàm mó hình $\eta(\theta)=\left(\eta\left(x_{1}, \theta\right), \ldots, \eta\left(x_{n}, \theta\right)\right)^{T}$ tại lấn cộn ước lượng họp lỳ cục đại $\hat{\theta}$ dược kháo sát cho trường hợp mợt nhóm các tham số quan tâm.

Tó Văn Ban

Học Viện Ky thuột Quấn sư

100 Hoàng Quớc Việt, Cởu Gióy Hà Nộ 
On the stablity of the characterizotion of the $\epsilon$-geometric composed variable

\section{Nguyĕ̃n Hữu Bảo'}

Tóm tắt: Let $X_{1}, X_{2}$, be nonnegative independent identically dlstributed random variables. Let $N$ be independent of $X_{j}(\forall j)$ with the geometric distribution function.

In (1) and (2), is called the geometric composed variable and has some characterizations in this article, we consider the random variable.

$$
Z=\sum_{j=1}^{N} X_{j}
$$

Where $N$ has geometric law and $M$ is Independent of $N, E M<\varepsilon^{\alpha}(\varepsilon \rightarrow 0), \alpha>$ 1. We proved that $N_{\varepsilon}$ shall be the e - geometric composed varlable. If we call $G(x)$ and $G_{\varepsilon}(x)$ to be the distribution functions of $Z$ and $Z_{\varepsilon}$ respectlvely then:

$$
\rho\left(G, G_{\varepsilon}\right) \leq C_{1} \varepsilon+C_{2} \varepsilon^{\alpha-1}
$$

Where $\rho(. ;$.$) is metric in the space of distributions$

$$
\rho\left(G, G_{\varepsilon}\right)=\sup _{x \in \mathrm{R}^{1}}\left|G(x), G_{\varepsilon}(x)\right|
$$

and $C_{1}, C_{2}$ are the constants independent of $\varepsilon$.

1 Nguyễn Hữu Bảo

Đạl học Thuy Lợ

175 Tơy Son, Đớng Đa. Hà Nội 


\section{Về một đlều kiện đủ luột mạnh só lớn}

\section{Phạm Xuân Bình ${ }^{1}$}

Tóm tắt: in this paper we shall introduce a suffcient condition for the Strong Large Number Law. From it's Corollary we see that if $X_{n}, n=1,2, \ldots$ is a sequence of independent random variables such that $E X_{n}=0,\left|E X_{n}\right|^{1+\delta} \leq C$ for some $C>$ $0,0<\delta \leq 1, n=1,2, \ldots$ then

$$
\frac{1}{n^{\frac{1}{1+s}} \ln n} \sum_{k=0}^{\infty} X_{k} \rightarrow 0 .
$$

\section{Pham Xuån Bình}




\section{On the characterization of the geometric composed variables by constant regression}

\section{Phạm Văn Chüng'}

Tóm tắt: Let us consider random variable Where $X_{1}, X_{2}$ are independent identically distributed random variables and $N$ is independent of all $X_{j}$ with the geometric distribution function. In (1) and (2), $Z$ is called the geometric composed variable and has some characterization. In this paper, investigated the characterizations of $Z$ when $X_{j}(j=1,2)$ has the negative - binomial or exponential law and proved that if we call $f(t)$ to be the characterization function of $Z$ then $f(t)$ have to satisfy with some differential equations. Let $\lambda_{k}=X_{1}^{k}+X_{2}^{k}+X_{n}^{k}$, we also showed some the characterizations of $Z_{1}^{s}$ distributed function by the constant regression between $\lambda_{1}$ and the statistic $T$ which was pointed out in the concrete cases.

1 Phạm Vơn Chüng

Đai họ Kinh té Qức dån

bường Giáli Phơng. Hả Nợi 


\section{Các dỡy só tựa ngỡu nhiên hay là các dăy sớ có độ phân kỳ thăp}

\section{Vũ Hoài Chương' ' và Nguyễn Công Điều' ${ }^{2}$}

Tóm tắt: Phương pháp Monte Carlo vật lý (tên khác là mô phỏng) cần đến có ba tính chất: ngẫu nhiên, độc lập và phân bố đều của các dãy số, nhung phương pháp Monte Carlo số trị chỉ đòi hỏi tính đểu của chúng. Vi thế các dãy số phân bố đều hoàn toàn tất định ngày càng hữu dụng trong tính toán. Đó chính là các dãy số tụa ngẫu nhiên (quasi-random), hay còn gọi là các dãy số có độ phân kỳ thấp (low discrepancy sequences) hoăc coân ngẫu nhiên (sub-random). Trong các dãy số này người ta dùng độ phân kỳ thay cho phương sai.

Sau ph (ng pháp Monte Carlo ít lâu, bản sao tất định của phương pháp này, trong đó các số tụa ngẫu nhiên thay thế các sốngẫu nhiên hoợc gia ngẫu nhiên (pseudorandom)-, ra đời nhò̀ các nhà số luận. Tến gọi phương pháp tụa Monte Carlo (quasi Monte Carlo methods) được dùng đến lẩn đẩu tiên trong một báo cáo nghiên cứu vào năm $195 \mathrm{l}$ của R. D. Richtmyer (Mỹ). Sau đó 3 năm K. F. Roth (nguōi Anh, sé được giải thường Fields năm 1958) đã xác định một tốc độ hội tụ tối ư cho xớp xi các tích phân. Điểu đậc biệt là các só gia ngắu nhiên do các nhà thống kê đua ra. còn các só tụa ngẳu nhiên lại do các nhà só lự̂n. Các só này dùng đến nhiều khăi niệm và công cụ của lý thuyết số.

Các dăy số tụa ngẫu nhiên đáng kể nhắt gá̛n liền với tên các nhà toán học $\mathrm{J}$. van der Corput (Hà Lan, 1890-1975), J. H. Halton (Mȳ). J. M. Hammersiey (Anh, 19202004). I. M. Sobol (Nga), H. Niederreiter (áo), và H. Faure (Pháp).

1 Vũ Hoài Chương

Viện Công nghệ thông tin

Viện Khoa hộc và Công nghệ Việt Nam 18 Hoàng Quốc Việt, Cốu Giấy, Hà Nội vuhoai@ioit.ac.vn

2 Nguyễn Công Điếu

Viện Công nghệ thơng tin

Viện Khoa học và Công nghệ Viêt Nam 18 Hoàng Quốc Việt, Cấu Giấy, Hà Nội ncdieu@yahoo.com 


\section{Phăn fích liên tiớp}

\section{Tó Anh Düng?}

Tóm tắt: Lý thuyết hiện đại của phân tích liên tiếp xuắt phát đổng thời đo Anh và Mỹ do nhu cốu về cách thúc xem xêt mỡu hữu hiệu hon. Mậc dù trong thời gian qua. lý thuyết vế vớn đẻ phăn tích liến tiếp có nhiếu thành tụu nhung việc kiểm định tí số xác suớt liên tiếp vắn cơn chua được giải quyết hoản chinh. Mục đích của bãi báo cáo là đưa ra cái nhin tởng quan vể sụ phát triến gấn đây cửa việc kiểm định liên tiếp trong điếu klện phi Bayes, li thuyết phi quyết định. Trái với viẹćc kiếm đinhn tí số xác suất liên tiếp, kiểm định liên tiếp đóng được địnnh nghĩa bởi các ràng buộc dưng phi tuyến và thường được úng dụng vào dứ liệu được phân nhóm. Mục địch thú hai của bài của bài báo cáo này là sắp xếp lại sụ không cân bằng trong phân tích liên tiếp giữa viếc xem xét các bố trí thí nghiệm và suy luận thống kê. Vi việc chọn kiểm định liên tiếp bao gổm bài toán chọn luật dừng, dơ đó ta nên xem xét bố trí thí nghiệm một cách chính xác. Báo cáo này còn đề cộp đến những kết luận tù dữ liệu nhận được trong thí nghiệm bao gồm múc ý nghĩa và khoảng tin cộ̀y. Điều này đóng vai trò rất quan trọng trong thống kê mẫu cố định nhung nó hầu nhu bị bỏ qua trong khi làm về thống kê liên tiếp trong những năm gần đây. Báo cáo này chủ yếu trình bày các mô hình đơn gián, đặc biệt liên quan đến phân phối chuẩn. Ngoài ra còn có phần mở rộng cho việc xấp xỉ các mố hình phúc tạp bới các mô hinh đơn gián hơn.

Tô Anh Düng

Đại học Khoo học Tư nhiên

Đại học Qước gia thành phó

Hó Chí Minh

227 Nguyển Văn Cù, Quộn 5

Thành phơ Hớ Chí Minh

tadung@mathdep.hcmuns.edu.vn 


\section{Dynamics of Random and Stochastic populations}

\section{Nguȳ̄n Hữu Du'}

Tóm tắt: The aim of this talk is to introduce some results about the asymptotic behavior of a Lotka-Volterra equation with random coefficelnts or with white noise. It is shown that solutions of such a equation osccilate between 0 and $\infty$. Hence, the system is neither permanant nor persistent.

\footnotetext{
1 Nguyễn Hữu Du Khoa Toán co Tin hoc Đại học Khoa học tụ nhiên Đại học Quó́c gia Hà Nối 134 Nguyênn Trăi, Thanh Xuốn Hà Nợi nhdu2001@yahoo.com
} 


\section{Summary of Stable Random Process}

\section{Dưong Tón Dám' và Dưong Ngqc Hảo}

Tóm tắt: Stable Random Process radiates its fresh and specific traits; so it is indispensable to whom it may concern. By continuing the studies of Levy analysis in coordination with the special characteristics of the distribution of stability such as the nature of the apex, the dualistic correspondence and transformation, and the asymptotic presentation, the learners will additionally gain an insight of the whole structure of stable random process. Consequently, it is useful for the learners to further examine integral and differential calculi in accordance with the stable random process.

1 Dương Tôn Đóm

Đại học Quర́c gia Thành Phó Hớ Chí Minh

2 Dưong Ngọc Hỏo

Đại học Sư phạm Kỹ thuột

Thành phó Hơ Chí Minh

dnhao74@yahoo.com 


\section{Su hợi tỵ của 1-amarts trong khong gian Banach}

\section{Phạm Xuân Hà' vò Đinh Quaing Lưu²}

Tóm tắt: Báo cáo này đưa ra một số điều kiện cần và đủ để l amarts hai chỉ số trong không gian Banach hội tụ mạnh hầu chắc chắn.

1 Pham Xuån Hà Dại học Su phạm Hả Nôi

136 Xuấn Thuỵ, Cấu Giớy Hà Nội

2 Olnh Quang Lur

Vlên Toán học

Viện Khoa học và Cống nghể Viêt Nam 18 Hoàng Quóc Việt, Cắu Giớy Hà Nội

dqluu@math.ac.vn 


\section{Mớ hình đẩư khiớn ngởu nhiên với bước nháy \\ Dọ̆ng Thanh Hăi ${ }^{1}$ và Nguyônn Hóng Hòl ${ }^{2}$}

Tóm tắt: Trong bài báo nảy, chúng tôi trình bày một số kết qủa nghiên cưu với quá trình Markov bước nháy điểu khiển được. Mục tiêu của điếu khiến là cục tiểu hàm giá.

Sau khi xây dựng mố hình điều khiến, chủng tôii sẻ đưa ra các kết quá về sụ tồn tại chién lược tối un, dỡn ra phương trình tới ư Bellman đóii với già tối ư và một loạt các tính chất của chiến lược tới ưu và giáa tới ư.

Dạng Thanh Hái Họ̣c Viện Phơng không Không Quân

2 Nguyễn Hởng Hài

Viện Công nghệ Thông tin

Bợ Quóc Phơng

34 A Trồn Phú Hả Nợi 


\section{Vđ̛ cớc họp đởng Quanto trong toón tài chính}

\section{Nouyởn Thị Thuý Hớng ${ }^{1}$ và Trồn Hùng Thao ${ }^{2}$}

Tóm tắt: Nói một cách sơ lược, Quanto là loại hợp đồng tài chính trong một quốc gia nhung lại được định giá bằng một loại tiền không phải của quốc gia đó. Sau khi nêu những khái niệm ban đầu về Quanto, báo cáo trình bày mô hinh toán học Quanto, dụa trên một phương pháp xây dựng 2 quá trình chuyển động Brown có tương quan với nhau nhưng xuất phát tù 2 chuyển động Brown độc lập với nhau. Báo cáo cũng để cập tới việc định giá theo đổng đổ la $M y ̃$ các tài sán tài chính có mệnh giá theo đổng bảng Anh (để định ý) nhu: Họp đổng ký kết trước, Hợp đồng nhị phân (số hóa), Hợp đồng quyền chọn.

1 Nguyő̉n Thl Thứ Hớng

Hoc vién Cao học

kil Viên Toán hóc

18 Hoàng Quớc Việt, Cớu Giớy, Hả Nớ

2 Trón Hùng Thao

Viên Toán hoc

Viện Khoa học và Công nghệ Việt Nam

18 Hoàng Quóc Viẹt

Cớu Giớy, Hà Nộ

ththao@math.ac.vn 
On a probabillty metric based on trotter operator and some applications in theory of limit theorems

Trờn Lộc Hùng'

Tóm tắt: The main purpose of this paper is to present a probability metric based on weli-known Trotter's operator. Some applications in approximation problems concerning the rates of convergence in limit theorems for independent random variables are established.

Trớn Lợc Hùng

Khoa Toán, Đại học Khoa học Huế

77 Nguyễn Huệ. Huế

thung@hueuni.edu.vn 


\title{
Central IImit theorem for the functional of jump Mankov process
}

\author{
Nguyển Văn Hữu ${ }^{1}$, Vương Quăn Hoàng ${ }^{2}$ và Trờn Minh Ngọc ${ }^{3}$
}

Tóm tắt: In this work we consider a jump Markov process $\left\{X_{t}, t \geq 0\right\}$ with the Borel state space $(E, B)$ and with the state transition intensity $q(x, A), x \in E, A \in B$ Support that

$$
\varphi: E \rightarrow \mathrm{R}
$$

is measureabie.

We have proved that under some conditions imposed on $\varphi$ and on the probability distribution of the process, the distribution law of the integral functional of the process

$$
\frac{1}{\sqrt{T}} \int_{0}^{T} \varphi\left(x_{t}\right) d t
$$

Converges to the normal law $N\left(0, \sigma^{2}\right)$ as $T \rightarrow \infty$, where the asympotic variance $\sigma^{2}$ is defined by $\varphi$ and $q$.

in particuiar we also give some conditions for asympotic normally of the total time length during which the process $\left\{X_{t}, t \geq 0\right\}$ visits a state when $E$ is discrete

1 Nguyẽn Văn Hữu

Dạl học Khoa hoc tu nhien

Đại học Quóc gia Hà Nội

334 Nguyẽnn Trăi, Thanh Xuân Hà Nội

huunv@vnu.edu.vn

2 Vưong Quân Hoàng

Cóng ty EMISCOM

3 Trởn Minh Ngoc

Đại học Khoa học tư nhiên

Đại học Quớc gia Hà Nợl

334 Nguyĕ̃n Trăi, Thanh Xuån Hà Nộl

ngoctm@vnu.edu.vn 
Mớ phỏng dọi lự̂ng ngău nhiớn và quá trình ngău nhiên

\section{Phạm Văn Khănh'}

Tóm tắt: Trong báo cáo này tôi đưa ra co sớ ly thuyết và các thuợt toán để mô phỏng các ĐiNN, lám co sód cho các quá trình tính toán phúc tạp hơn. Điểm quan trọng trong báo cáo này là đua ra cóc thuợt toán mố phóng các quá trình ngău nhiên khớng thuớn nhớt

Pham Văn Khánh

Học Viến Kỹ thuợ̂t Quốn su

100 Hoàng Quóc Việt

Cắu Giớy, Hả Nội 


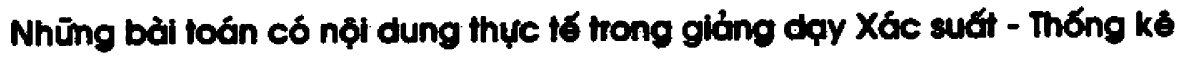
Phạm Văn Khănh ${ }^{1}$

Tóm tắt: Trong báo cáo này đua các bài toán với tu cách là những bài tộp lớn trong giáng dạy môn Xác suất - Thống kê. Đó là những bài toán thục tế, vận dụng những kiến thúc cơ bản về XSTK và quá trình ngẫu nhiên để giải quyết, có tác dụng giáo dục tích cực cho học viên sau khi tốt nghiệp có thể vận dụng các kiến thúc đã học về chuyển môn XSTK trong công tác.

1. Bài toán 1: Tính quãng đường trung bình mà 1 xe cúu thương phái đi khi có tín hiệu cốp cứu.

2. Bài toán 2: Phương pháp Crofton's đế tính kỳ vọng trong mợt só băi toán.

3. Băi toán 3: Định vị phương tiện phục và phån vùng tới ư.

Pham Văn Khánh Học Viện Kỹ thuột Quån sụ 100 Hoáng Quóc Việt

Cắu Giớy, Hà Nợi 
Applying probabilistic model for ranking Webs in multi-context

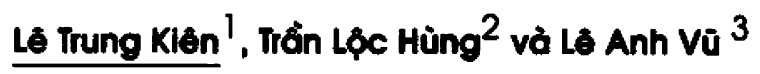

Tóm tá̛t: Xây dụng thuợt toán MPageRank dụa trên mợt mố hinh xác suá̛i mơi nhằm cải tiến thuợt toán PageRank trong cớng cụ tìm kiếm Webs Google.

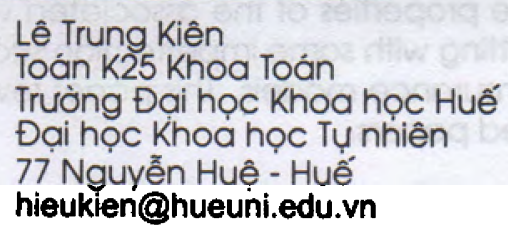




\title{
Review of Efficlent Partial Hedging
}

\author{
$\underline{\text { Nguyēn Thành Long }}{ }^{1}$
}

Tóm tắt: In a complete financial market a given contingent claim can be replicated by a self-financing trading strategy, and the cost of replication defines the price of the claim. In incomplete financial markets one can still stay on the safe side by using a "superhedging" strategy. But from a practical point of view the cost of superhedging is offen too high. Also perfect (super-) hedging takes away the opportunity of making a profit together with the risk of a loss.

Suppose that the investor is unwilling to put up the initial amount of capital required by a perfect (super-) hedge and is ready to accept some risk. What is the optimal "partial hedging" which can be achieved with a given smaller amount of capltal? In order to make this question precise we need a criterion expressing the investor's attltude towards the shortfall risk in terms of a general convex loss function I. Convexity of I corresponds to risk aversion. The shortfall is defined as the expectation of the shortfall weighted by the loss function. The aim is to minimize this shortfall risk, given some capital constraint. Instead we could prescribe a bound on the shortfall risk and minimize the cost. In other words, we are looking for hedges which are efficient with respect to the partial ordering defined by the shortfall risk and the initial capital. These efficient hedges allow the investor to interpolate in a systematic way between the extremes of a perfect hedge (no chance of making a profit) and no hedge (fuil risk of shortfall, full chance of profit) depending on the accepted level of shortfall risk. This problem was introduced by Follmer and Leukert (2000). The authors solved for a complete market as well as for general semimartingale market. Using changes of measures and optional decomposition under constraints. Pham (2002) and Long (2004) show some qualitative properties of the associated value function in a more general semimartingale setting with some imperfection such as constrained portfolios, large investors and reinsurance models. This paper reviews the solutions presented in the abovementioned papers.

We begin In section 2 by defining our optimization problem for a given contingent claim $\mathrm{H}$ in a general semimartingale setting. Exisitence and essential uniqueness of the solution is shown in section 3 . The optimal strategy consist in (super-) hedging a suitable modified claim $=\mathrm{H}$ where is some "randomized test" taking values in $(0,1)$. In section 4, we consider the complete case where the equivalent martingale measure is unique. The construction of the optimal test can leads to an application of the Neyman Pearson lemma. Alternatively, we can use methods of convex duality. In section 5. we use a variant of the methods of Kramkov-Schachermayer in order to describe the structure in general case. In the incomplete case we rely on the basic duality theorem In KS(1997). In section 6, we study an extension of the model where the market is established in a more general semimartingale setting that includes models with some "imperfection" in a spirit of the paper of Pham and Mnif 
(2002) or that of Long (2004). Again, in that case we can rely on the duality theorem in Long (2004) or Pham and Mnif (2002).

1 Nguyễn Thònh Long

Ban Hợ tác Quóc tế

Ử ban chúng khoán Nhà nước

164 Trớn Quang Khál, Hà Nội 
Chặt cốt yếu và sụ hộl tụ của cóc trò chol véc to công bằng dồn theo thời gian

\section{Dinh Quang Lư}

Tóm tắt: Khái niệm chặt cốt yếu đã quen biết và thường được sư đụng để thư được sụ hợi tụ theo phân phối. Trong bài báo này chặt cốt yếu được đưo vào nhu một điều kiền cần và đủ cho sụ hội tụ theo chuẩn Pettis và hẩu chắc chắn của các trò choi công bằng dần theo thời gian và mactingan giới hạn yếu. Một só́ dạng định lý của lto - Nisio được đưa ra nhu hệ quá dễ dàng.

Dinh Quang LuT

Viên Toán học

Viền Khoa học và Cóng nghệ Việt Nam

18 Hoàng Quớc Viềt. Cầu Giấy. Hà Nội

dqluu@math.ac.vn 
Sụ hội tụ của các trò chol trong khỏng gian Banach có tính Radon - Nikodym

$$
\text { Dinh Quang Lưu' và Nguyễn Thị Mìn }
$$

Tóm tá̛t: Bài báo đưa ra các điều kiện cần và đủ các trò chơi cớng bằng dờn theo thời gian $L^{\prime}$ bị chăn trong không gian Banach tống quát hội tụ theo xác suất.

Dinh Quang Lư

Viên Toán học

Viện Khoa học và Công nghẹ Việt Nam 18 Hoàng Quớc Viêt, Cồu Giốy, Hà Nội dqluu@math.ac.vn

2 Nguyễn Thị Mỳ $\mathrm{Hocc}$ viên Cao họ $\mathrm{KI} 3$

Dại học Sư phạm Hà Nội

136 Xuân Thuỳ, Cău Giáy, Hà Nồ 


\section{Khöng gian Gauss}

\section{Le Thị Xuán Mai ${ }^{1}$}

Tóm tớt: Đưa ra định nghia tởng quá̛t vế quá trình Gauss, một só tính chá́t đọ̆c biệt của khống gian Gauss, và dụ bơo của quá trình Gauss.

Lê Thị Xuån Mai

Đại học Khoa học Tư nhiên

Đại học Quóc gia Thành phó Hớ Chi Minh

227 Nguyễn Văn Cù, Quận 5, Thành phó Hớ Chi Minh

Itxmai@mathdep.hcmuns.edu.vn 


\section{Vế hal định lý co bờn của Tớn tà̀ chinh}

\section{Hoòng Dúc Mạn' 1}

Tóm tắt: Báo cáo trình bày hai định lý cơ bản của Toán tài chính trên cơ sở của Giải tích ngẫu nhiên, nêu lên một số nhận xét về vai trò và tác dụng của chúng trong nghiên cứu Toán tài chính. Đổng thời chúng tôi cũng nêu lên một vài hướng mở rộng của các Định lý này.

Hod̀ng Dúc Mạnh

Dạ học Kinh té Quóc dón

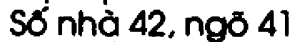

Thái Hà. Hà Nộl

hdmanh2003@yahoo.com 


\section{Hàm phờn tớn có điléu kiận}

\section{Oăng Th! Tớ Nhu ${ }^{1}$}

Tóm tắt: Mục điich chính của báo cáo náy lả xây dụng hàm phân tán có kiêu kiện cưa bién ngẵu nhiên $Y$ trong đlểu kiện đă biết biên ngẵu nhiên.

Đọ̆ng Thị Tó Nhu

Đại học Khoa học Hué

77 Nguyễn Huế. Thành phó Huế

dangnhu@yahoo.com 
Phương trinh Langevin phàn thứ và ứng dụng trong mố hình lăi suát

$$
\text { Trồn Trọng Nguyên' }
$$

Tóm tắt: Phương trình Langevin ngẵu nhiên là một phương trình quen thuợc trong Giál tích ngỡu nhiên. Sủ dựng phương trình nờy, năm 1977 Vasicek đă để sứ̛́t một mố hình ngãuu nhiên cho lăi sứ̛́t trái phiếu

$$
d r_{t}=\alpha\left(\gamma-r_{t}\right) d t+\rho d W_{t}, \alpha>0,
$$

trong đó $r_{t}$ là lăi suá́t trái phiếu tọi thời điểm $t \geq 0, \gamma$ là tỷ lệ trung bình của glá trái phiếu, các tham só $\alpha, \beta, \gamma$, và $\rho$ là các hằng só, $W_{t}$ là một chuyển đợng Brown

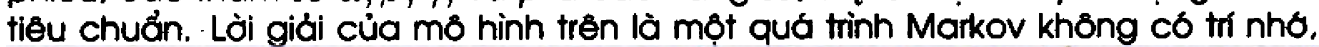
phản ánh những quá trình lãi suất trái phiếu mà giá trị tại thời điểm tương lai chỉ phụ thuộc văo giá trị tại thời điểm hiện tại, không phụ thuộc vão lịch sủ lâu dòi trước đó của quá trình. Thục tế cho thấy, nhiều biến động trong tài chính chịu ánh hưởng bởi những biến động trong quá khú. Trong báo cáo này, dụa trên phương trình Langevin phân thú, chúng tôi đề suất một mô hình mở rộng của mô hình Vasicek cho phép mô tả các quá trình lãi suất trái phiếu có tính phụ thuộc

$$
d r_{t}=\alpha\left(\gamma-r_{t}\right) d t+\rho d W_{t}^{H}, \alpha>0,
$$

trong đó $W_{t}^{H}$ là một chuyến động Brown phân thú với tham só Hurst $H, 0<H<1$. Chúng tôi chi ra sụ tởn tại lời giái của mó hinh và phương pháp xá́p xi lời giái đó. Trong trường họp $H=\frac{1}{2}$, mô hinh này trờ về mố hình Vasicek.

\footnotetext{
Trồn Trọng Nguyên

Khoa Toón

Đại học Sư phạm Hà Nợi 2

Trị trớn Phúc Yènn, Vinhn Phúc

ttnguyenvp@hn.vnn.vn
} 


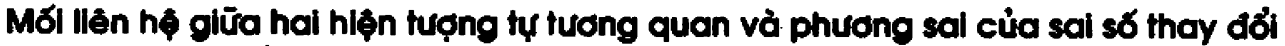

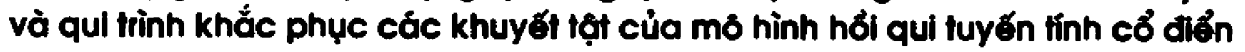

\section{Doỏn Irờn Phú ${ }^{1}$ vò Vũ Huyến Trang ${ }^{2}$}

Tóm tắt: Có nhà chuyên môn đã nói: Kinh tế vi mô, Kinh tế vĩ mô và Kinh tế lượng là ba trụ cột nâng đỡ toà lâu đài kiến thúc kinh tế. Mục đích của Kinh tế lượng là xây dựng các hàm hồi quy. Nhung để những hàm hổi quy mẫu thu được có thể dụ báo hiệu quả quá trình kinh tế, xã hội thì cần phi tho mãn một số gia thiết co bản, trong đó hai gia thiết quan trọng nhất là phương sai của sai số không đổi và không có hiện tương tụ tương quan.

Đáng tiếc rằng trong thục tế các gia thuyết trên thường xuyên bị vi phạm và việc khắc phục chúng khá phúc tạp, đặc biệt là đối với các nhà kinh tế. Điểu này hạn chế rất lớn việc úng dụng công cụ Kinh tế lượng vào thục tế. Báo cáo này chỉ ra mối liên hệ giữa hai hiện tượng phương sai của sai số thay đổi và tụ tương quian. tù đó đưa ra qui trình khắc phục một cách hiệu qủa, nhanh chóng hai hiện tượng này nói riêng và các khuyết tột của mô hình hổi quy tuyến tính cổ điển nói chung.

1 Doơn Trớn Phú

Bớ mớn Toán Đại họ Thương Mại

Mai Dịch, Tù Liếm, Hà Nội

huyentrang010981@yahoo.com

2 Vũ Huyển Trang

Bợ mốn Toán Đại học Thương Mại

Mai Dịch. Tù Liểm, Hà Nợi

huyentrang010981@yahoo.com 


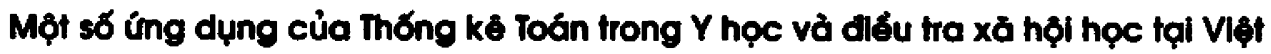
Nam

\section{Hớ Đăng Phúc ${ }^{1}$}

Tóm tắt: Thống kê toán học có vai trò rất quan trọng trong nhiều ngành khoa học tụ nhiên và xã hội, có tiềm năng úng dụng thục tế to lớn, nhất là khi có sụ trợ giứp của máy tính. Tuy nhiên ở Việt Nam, việc giáng dạy và úng dụng thống kê còn chưa được phát triển và cỏn nhiều hạn chế. Với tiến trinh hội nhập thế giới của đất nước, công cụ này đã tùng bước được đưa vão sủ dụng tại Việt Nam, hỗ trợ cho nhiều nghiên cúu của một số ngành, đặc biệt là ngành $Y$ trong những năm gần đây. Bản báo cáo trình bày một số kết qưa úng dụng thống kê toán trong linh vục $Y$ học và ngành có liên quan là Điều tra Xã hội học, đồng thời giới thiệu những phương pháp Phân tích số liệu thường được dùng trong các nghiên cứu đó.

Hơ Đŏng Phúc

Viến Toán học

Viện Khoa học vả Công nghệ Việt Nam

18 Hoáng Quóc Việt, Cấu Giáyy, Hà Nội

hdphuc@math.ac.vn 


\section{Một só định lí glớl hạn dạng luột só lớn}

\section{Nguyễn Văn Quảng $^{1}$ và Lể Văn Thành ${ }^{2}$}

Tóm tắt: Báo cáo giới thiệu các kết quả nghiên cưu của chúng tôi cùng với các cộng sụ trong và ngoài nước trong vài năm gần đây về Luật số lớn. Cụ thể là. chúng tôi sẽ trình bày các vấn đề sau đây:

-Luật số lớn đối với dãy các biến ngẫu nhiên phù hợp theo khốí.

-Luật số lớn đối với dãy các biến ngẵu nhiên phù hợp theo khối.

-Luật mạnh số lớn đối với máng hai chiểu các biến ngẫu nhiên độc lập theo khối. trục giao theo khối.

-Luật mạnh số lớn dạng Chobanyan - Mandrekar đối với dãy các biến ngẫu nhiên nhận giá trị trên không gian Banach thoả mãn điểu kiện $B$ theo khối.

-Khái niệm hội tụ đầy dủ theo trung binh bộc $p$ và một số kết quả liên quan.

-Luật yểu số lớn đối với dãy nhiểu chi số các toán tủ đo được trên đậi số von Neumann.

-Luột yếu só lớn đới với dãy các toán tủ đo được phù họp trên đội só von Neumann.

Nhiểu ví dụ và phán ví dụ sê dược thlết lộp. Một sర kết quá nhu luột số lớn Kolmogorov, luột sớ lớn Rademacher-Menshov cho máng hai chiểu, luật MarcinkiwiczZygmund.... sẽ đượ mơ rộng.

\section{Tài liệu tham khảo}

1. Chobanyan, S. and Mandrekar. V. (2000) On Kolmogorov SLLN under rearrange: ments for "orthogonal" random variables in a $B$-space. J. Theoret. Probab. 13. (1) 135--139.

2. Gaposhkin, V. F. (1995) On the strong law of large numbers for blockwise independent and blockwise orthogonal random variables. Theory Probability and its applications. 39(3), 677-684.

3. Gut, A. (1978) Marcinkiewicz law and convergence rates in the law of large numbers random variables with multidimensional indices. Ann. Probability. 6. 469-482.

4.P. Hall, C. C. Heyde;( 1980) Martingale Limit Theory and its Application, Academic Press, Inc. New York 1980.

5. Loeve, M. (1977) Probability Theory Springer-Verlag, New York, 4th ed.

6. A. Luczak, (1985) Laws of large numbers in von Neumann algebras and related results.Studia Math. 81 231-243.

7. Nguyen Van Quang. (1996) The law of large numbers for two dimensional arrays of orthogonal operators in von Neumann algebra. Acta Math.Vietnam. 31(1) 15-25.

8. Nguyen Van Quang, (2003) On the weak law of large numbers for d-dimensional arrays in von Neumann algebra, Vietnam. Journal of Math 31(3). 261-265. 
9. Nguyen Van Quang, (2004) On the weak law of large numbers for adapted sequences in von Neumann algebra. Acta. Math. Vietnam 29(3).231-236.

10. N. V. Quang and L. V. Thanh. On the strong law of large number under rearrangements for sequences of "blockwlse orthogonal" random elements in Banach spaces. Submitted in J. Theoret. Probab.

11. Nguyen Van Quang and Nguyen Duy Tien, (1992) On the law of large numbers for martingale differences in von Neumann algebra, Acta Math. Vietnam. 17(2) , 13-22.

12. Nguyen Van Quang and Nguyen Duy Tien.(1997) The strong law of large numbers for d-dimensiontional arrays in von Neumann algebra. Theory of Probability and its Applications 41 (3) 569-577.

13. Rosalsky, A, Thanh, L. V and Volodin, A. I. On Convergence of Normed Sums of Independent Random Elements in Banach Spaces. Submitted in Stochas. Anal. Apll.

14. L. V. Thanh and N. V. Quang. (2005) Strong laws of large numbers for blockwise adapted sequences. Vietnam. Journal of Math 33 (1).1-8.

15. L. V. Thanh. On the $L^{p}$-convergence for Multidimensional Arrays of Random Variables. To appear in International Joumal of Mathematics and Mathematical Science.

1 Nguyễn Văn Quóng Khoa Toán Đại học Vinh Thành phơ Vịnh, Nghệ An nvquang@hotmail.com

2 Lè Văn Thănh Khoa Toán Đại học Vinh Thành phơ VInh. Nghệ An Ivthantivinh@yahoo.com 


\section{Vớn đồ cợng tính và mó hình ARCH}

\section{Nguyễn Hơ Quỳnh'}

Tóm tá̛:: Giới thiệu các kết quả chủ yếu của hai chuyên gia về chuỡi thời gian (Granger và Engle) duợc giải Nobel (trong linnh vực nghiên cưu tài chính) nưm 2003.

Nguyễn Hổ Quỳnh Khoa Toán ứng dụng

Đại học Bách Khóa Hà Nội iĐọi Cổ Việt, Hà Nộl hoquynh@hn.vnn.vn 


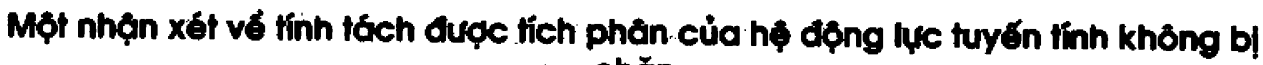
chọ̆n

\section{Doòn Thál Son ${ }^{1}$}

Tóm tá̛t: Trong báo cáo này chúng tôi chứng minh rằng tồn tại một hệ động lực tuyến tính có phân hoạch dominated mà không là bển vững trong không gian những hệ động lực tuyến tính không bị chặn $\mathcal{G}(d)$ với tô pô đểu.

Đoàn Thái Son

K6 Toán Cư nhẳn nài năng

Đại họ Khoa học Tụ nhiến

Đại học Quóc gla Hă Nộl

334 Nguyễn Trợ, Thanh Xuớn. Hă Nợi

sonk6@yahoo.com 


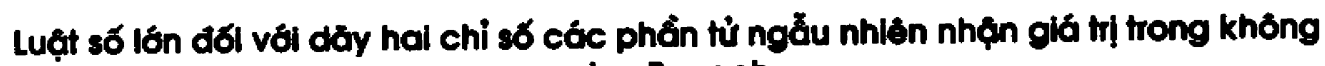
glan Banach

\section{Lê Vŏn Thönh'}

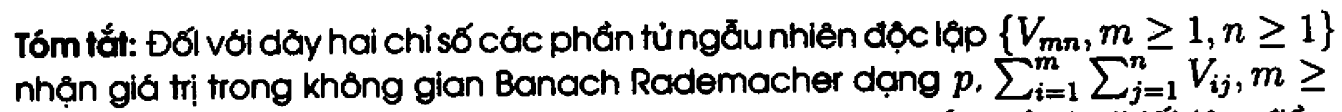
$1, n \geq 1$. Vể luật só mạnh vả sụ hợi tụ trong $L^{r}$, cớc kết quá đă thiết lộp điểu kiện đấ có $\sum_{i=1}^{m} \sum_{j=1}^{n} \frac{V_{i j}}{m^{\alpha} n^{\beta}} \rightarrow 0$ hởu chắc chớn và $\sum_{i=1}^{m} \sum_{j=1}^{n} a_{m n i j} V_{i j} \rightarrow 0$ trong $L^{r}$ khi $\max \{m, n\} \rightarrow \infty$. Kết quá vấ luợ̂t sớ lớn, cớc điếu kiện được thiết lộp để cho $\sum_{i=1}^{T_{m}} \sum_{j=1}^{T_{n}} \frac{\left(V_{i j}-c_{i j m n}\right)}{m n} \rightarrow{ }^{p} \infty$, trong đó $c_{i j m n}=E\left(V_{i j} I\left(\left\|V_{i j}\right\| \leq m n\right)\right)$. $i, j, m, n \geq 1$ vả $\left\{\tau_{n}, n \geq 1\right\}$ ià hai dăy các biến ngău nhiên nhặn giá trị nguyên dương. Nhiếu ví dụ đă được minh hoạ.

1 Lee Văn Thành

Dại học Vinh

Thành phó Vinh, Nghệ An

Ivthanhvinh@yahoo.com 


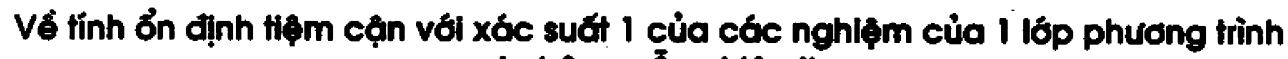
sai phớn ngăư nhiên lto

\section{Phan Đức Thành ${ }^{1}$ và Phan lô $\mathrm{Na}^{2}$}

Tóm tắt: Trong báo cáo này chúng tôi đưa ra 1 tiêu chuẩn và các điều kiện đủ đại số đối với tính ổn định tiệm cận với xác suất 1 của nghiệm của 1 lớp hệ phương trình sai phân ngẫu nhiên lto tuyến tính.

1 Phan Đức Thành Đoi hoc Vinh

Thành Phó Vinh. Nghệ An

2 Phan lê Na Đại học Vinh Thành Phó Vinh, Nghẹe An phanlena@yahoo.com 
Phương pháp Toón họe phớn tích nưi ro tài chinh Trồn Hùng Thao'

Tóm tắt: Báo cáo nêu lên phương pháp toán học đấ phân tích nưi ro nơl chung bằng cách xác ạinh các xác suất thlật hại. Co sở của phương pháp này là Định lý Lundberg - Cramer nới tiéng mà sụ phát minh đẳu tiên hới đẩu thé kỷ XX đả tưng dược so sánh ngang tổm với việc phát klến của Bachelier và Elnsteln vể chuyến động Brown. Báo cáo nhìn nhộn lại sụ kiện này trên quan điểm xác suớt lý thuyết hiện đại. Ngoải ra chúng tơi cũng nêu nhūng phương pháp phấn tích rủi ro tín dụng với mô hinh Merton và mó hình Jarrow-Lando-Turbull vơ việc xớy dụng các định múc rủi ro tín dụng dụa trên lý thuyết xích Markov.

1 Trốn Hùng Thao

Viên Toán học

Viện Khoa họ̣ và Cớng nghể Vlệt Nam 18 Hoáng Quớc Việt, Cởu Giáy, Hà Nội ththao@math.ac.vn 
The extension of random mappings

\section{Đặng Hùng Thắng}

Tóm tăt: In this report, the problem of extending the domain of a random mapping from the space $X$ of deterministic inputs to certain class of $X$-valued random outputs is discussed. The motivation of this study is the problem of defining the stochastic integral of random functions with respect to the Wiener process (the Ito stochastic integral) and the composition of two random operators.

Dợng Hừng Thắng Khoa Toán co Tin hoc Dại học Khoa học tư nhiên Đọi học Quóc gia Hà Nợi

134 Nguyẻn Trăi, Thanh Xuân Há Nội hungthang@hn.vnn.vn 


\section{Blớu diễn phơ của toán tử ngắu nhiôn \\ Nouyởn Th!̣h ' và Oăng Hùng Thắng 2}

Tóm tắt: Toán tủ ngẫu nhiên là một khái niệm được ngẫu nhiên hoá của khái niệm toán tử, và do đó rất nhiều vấn để vể toán tử ngổu nhiên được đặt ra, ví dụ, một câu hỏi tụ nhiên là các kết quá vể toán tủ sẽ nhu thế nào khi đặt trong môi trường ngẫu nhiên. Định lý biểu diễn phổ rất quen thuộc và đóng một vai trò quan trọng trong lý thuyết vể toán tủ, trong báo cáo này chúng tôi sẽ đề cập và giải quyết vấn để vể biểu diễn phổ của toán tủ ngẫu nhiên.

1 Nguyễn Thịnh

Khoa Toán - Co - Tin hoc

Đại Học Khoa Học Tụ Nhiên

Đại học Quốc gia Hà Nội

nguyenthinh@vnu.edu.vn

2 Đọ̆ng Hùng Thắng

Khoa Toán - Cơ- Tin học

Đai Hoc Khoa Học Tụ Nhiên

Đại học Quốc gia Hả Nội

hungthang@hn.vnn.vn 


\section{Spectral Represetation of Multiply Self-Decomposable Processes}

\section{Nguyĕ̃n Văn Thu' ${ }^{1}$}

Tóm tắt: It is well-known that each centered Gaussian process admits a stochastic integration represetation via a "Gaussian noise". Similarly, as developed by M. Shilder,J.Kuelbs,Jr. C.D. Hardin, ..., each stable process can be represented in terms of a "stable noise". Some authors such as K.Urbanik, W.A.Woyczynski, G. Maruyama have recently obtained a general representation for infintely divisible stochastic processes. Especially, the most general and complete results in this direction have been obtained by J Rosinski and B. S. Rajput. The main purpose of this repport is to prove that each multiply self-decomposable process can be represented as a stochastic integration in terms of " self-decomposable noise". Moreover, in the case of stationary multiply self-decomposable processes, we prove a unique representation in which some measurable flows and cocycles are involved. Thus a relashionship between our underlying problems and that in stochastic oynamic systems is established.

1 Nguyễn Văn Thu

Viên Toán hơc

Vlện Khoa học và Công nghệ Việt Nam

18 Hod̀ng Quóc Việt, Cớu Gióy, Hà Nội

nvthu@math.ac.vn 


\section{Lịch sử cóc định lý glớl hạn}

\section{Nguyển Duy Tión ${ }^{1}$ và Phan Vlắt Thư ${ }^{2}$}

Tóm tắ: Chúng tôi xin giới thiệu tóm tắt những kết quả chính của lý thuyết các định lý giới hạn của tổng các đại lượng ngẫu nhiên độc lập.

Đây là những kết qu nhận được tù khi cuốn sách của Bernoulli ra đời cho đến lúc xuất hiện cuốn sách chuyên kho cơ bản của Gnedenko và Kolmogorov (Gnedenko and Kolmogorov 1954) dành cho lý thuyết này năm 1949.

Do những thông tin loại lịch sủ, trước tiên quan trọng về mặt phương pháp luận đối với chúng ta, đưa ra những kết qủa ghi nhận như nhũng mốc lịch sủ của sự hình thành lý thuyết hiện đại của tổng các đại lượng ngẫu nhiên độc lập nên chúng ta sẽ xuất phát tù những biểu thúc truyển thống, nếu thấy đó là thích hợp hơn.

\footnotetext{
1 Nguyễn Duy Tiến

Khoa Toán - C - Tin học

Dại Học Khoa Hoc Tư Nhiên

Đại học Quóc gia Hà Nộ।

nduytien@netnam.org.vn

2 Phan Viết Thu

Khoa Toán - C - Tin hoc

Đạl Học Khoa Học Tự Nhiên

Đạl học Quóc gia Há Nội
} 
Vàl ý klớn trao đới vớ giảng dạy Thớng kể ứng dụng cho các ngành kinh ţ, khoo học xỏ họi

\section{Köng Tب ${ }^{\prime}$}

Tóm tắt: Thống kê úng dụng đóng vai trò quan trọng trong việc nghiên cứu các quy luật của kinh tế và xã hội. Thống kê cho chúng ta một công cụ, một "công nghệ" nhằm phát hiện các quy luột (vốn rất phức tạp) của các hiện tượng kinh tế và xẫ hội.

Trong báo cáo này chúng tôi muốn trao đổi một số suy nghĩ về giáng dạy Thống kê úng dụng cho các ngành kinh tế, xã hội và thư đề xuất một chương trình khung cho môn học.

Kông Ty

Khoa Toán úng dưng

Đạl họ Bách khoa Hà Nội

1 Đọ̣i Cớ vlệt. Hà Nội 


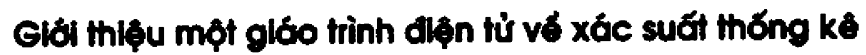
Đà̀ Quang Tuyơnn ${ }^{1}$ Hớ Đăng Phúc ${ }^{2}$ và Trờn Mạnh Tuớn ${ }^{3}$

Tóm tắt: Một giáo trình điện tư về xác suất thống kê đưa ra nhằm giủp sinh viên học tộp vể môn này cũng nhu hỗ trợ thày giáo giáng dạy có thêm công cụ. Giáo trình điện tủ có thể tái vể tù địa chi http://www.angelfire.com/oz/xstk/.

1 Đào Quang Tuyến

Viện Toán học

Viện Khoa học và Công nghế Việt Nam

18 Hoàng Quốc Việt, Cởu Giớy, Hà Nội

dqtuyen@math.ac.vn

2 Hơ Đăng Phúc

Vlển Toán học

Viện Khoa hộ và Công nghệ Việt Nam

18 Hoàng Quóc Vlệt, Cớu Giớy, Hà Nội

hdphuc@math.ac.vn

3 Trớn Mạnh Tuấn

Viện Khoa học và Công nghệ Việt Nam

18 Hoàng Qứć Việt, Cớu Gláy, Hà Nợi

tmtuan@vast.ac.vn 


\section{Val trò của độ đơ ngỡu nhlèn trong thớng kê}

\section{Nguyănn Bác Văn ${ }^{1}$}

Tóm tắt: Các phân phối xác suất ngẫu nhiên đóng vai trò cơ bản trong thống kê. Ngay tù khởi đầu thống kê cổ điển, định lý nổi tiếng Glivenko-Cantelli đã xác lập tổ hợp tuyến tính lồi của những độ đo Dirac ngẫu nhiên hội tụ đến phân phối cơ sở của dữ liệu. Trong quá trình phát triển kinh tế-xã hội, khoa học thống kê phải đối mặt với những hiện tượng biến đổi nhanh, trong đó phân phối xác suất của dũ liệu ngẫu nhiên chỉ là phân phối một thoáng.

Báo cáo bàn về độ đo xác suất ngẩu nhiên về cơ sở lý thuyết toán học, và về úng dụng trong mô hinh hóa thống kề bao gồm thống kê Bayes. 
Mố Phỏng Mọt Sớ Bài toón Xác Suăt đă tính só $\pi$ Bùl Quang Vü

Tóm tớt: Xồy dựng chương trinh tính sớ $\pi$ bằng Java thớng qua bảl toán chiéc kim

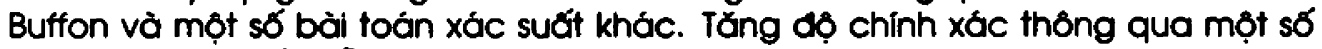
thuợ̂t toán tạo só ngẵu nhiên.

Bùi Quang Vũ

Đại học Khoa học Hué

77 Nguyên Huệ. Thớnh phó Hư

bqvu288@yahoo.com 
On the Convergence of two-parameter Multivalued Pramarts and Mils

\section{Vū viơt Yen'}

Tóm tớt: Real-valued martigales were first introduced and studied by Doob and later systematically extended to Banach spaces by a number of authors. On the other hand, mattigales, submartingales and Laws of large numbers of random sets have been also extensively investigated. The main aim of this report is to combine ideas and methods of the above approaches to study multivalued 1-pramarts and 1-mils.

Vū Vlét Yên

Khoa Toán, Đại học Su pham Hà Nốl

136 Xuo̊n Thuỷ. Cờu Gióy, Hà Nội 


\section{Danh sách đại biểu}

\section{Phan Thành An}

Viện Toán học

18 Hoàng Quốc Việt,

Cầu Giấy, Hà Nôi

E-mail: thanhan@math.ac.vn

2. Bùi Lan Anh

Đại học Sư phạm Hà Nội

136 Xuân Thuỷ

Cầu Giấy, Hà Nội

3. Nguyễn Tuấn Anh

Phổ thông trung học

Nguyễn Đúcc Cánh

Hải Phòng

Đại Họp, Kiến Thuy, Hải Phòng

\section{Nguyğn Th! Ngoc Anh}

Đại học Bách khoa Hà Nội

I Đại Cổ Việt.

Hai Bà Trung. Hà Nội

E-mail: ngocanha3_k44@yakoo.com

\section{Pham The Anh}

Học viện Kỹ thuột Quân sụ 100 Hoàng Quốc Việt

Cầu Giấy, Hà Nội

\section{Tạ Ngọc ánh}

Học viện Kỹ thuật Quân sụ

100 Hoàng Quốc Việt

Cầu Giáy, Hà Nội

\section{Tơ Văn Ban}

Học viện Kỹ thuật Quân su

100 Hoàng Quốc Việt

Cầu Giáy, Hà Nội

\section{Nguyēn Hữu Bảo}

Dại học Thuỷ Lọi
Tỡy Sơn, Đơng Đa, Hà Nội

9. Tạ Quốc Bảo

Đại học Thái Nguyên

E-mail: baotq10@yahoo.com

10. Hoàng Văn Bắc

Trường PTTH Đúc Trọng

Quốc Lô 20

Thị trá́n Liễn Nghia

Huyện Đức Trọng, Tỉnh Lâm Đồng

11. Nguyễn Thanh Bình

Khoa cao đẳng.

Trường Đại học SP Thái Nguyên

12. Phạm Xuôn Bình

Đai hoc Quy Nhon

170 An Duong Vưong

Quy Nhon, Binh Dinh

E-mall:vinhspiderman@gmall.com

13. Trần Duy Bình

Hoc viên cao học $\mathrm{K} 13$

Đại học Su phạm Hà Nội

14. Trần Cảnh

Đại học Xây dựng Hà Nội

55 Giái Phóng

Hai Bà Trưng, Hà Nội

15. Ngô Quốc Chung

Trung tâm Vật lý

Lý thuyết Abdus Salam, Italy

\section{Phạm Văn Chüng}

Dọi học KInh tế Quớc dôn

Đờng Tám. Hai Bà Trung

Hà Nợi

\section{Vũ Hoòi Chuong}

Viện Công nghệ thông tín (VASI)

18 Hoàng Quóc Việt 
Cồu Giấy, Hà Nối

E-mail: vuhoai@ioit.ac.vn

18. Noó Thé Cờng

Học viên Cao học

KII Viện Toán học

\section{Nguyỗn Dinh Công}

Viện Toán học

18 Hoàng Quóc Viêt

Cồu Giấy. Hà Nơ̂i

E-mail: ndcong@̈math.ac.vn

\section{0. Đỗ Văn Cưòng}

Đai học Khoa học tu nhién

Đai học Quóc gia Hà Nới

E-mail:manhkuong1982@yahoo.com

\section{Nouyễn Cao Cường}

Đai học Ngoai ngũ

Km 9 Thanh Xuån Hà Nợi

E-mail: hanagetsu@yahoo.co.jp

22. Nguyễn Quang Cuờng

Đại học Duy Tân

Đà Nẳng

E-mail: cnguyenquang@yahoo.com

23. Trờn Mạnh Cường

Đại học Khoa học tự nhiên

Đại học Quốc gia Hà Nội

334 Nguyễn Trăil. Thanh Xuån

Hà Nội

E-mail:cuongtm@vnu.edu.vn

24. Nguyễn Thanh Diệu

Dai hoc Vinh

E-mail: dieudhv@.yahoo.com

25. Nguyễn Quang Dong

Đại học Kinh tế Quốc dân

Phường Đồng Tâm

Hai Bà Trung. Hà Nội

26. Nguyễn Thế Dũng

Dại học Sư phạm Huế

E-mail: zungnguyen @hotmail.com

\section{Tó Anh Düng}

Đọi học Khoa học tụ nhiên

Đại học Quó́c gia

Thành phó Hớ Chí Minh

227 Nguyễn Vãn Cù̀, Q5

Thành phó́ Hố Chí minh

tadung@mathdep.hcmuns.edu.vn
28. Nguyễn Hữu Dư

Đại học Khoa học tư nhiên

Đạl học Quóc gia Hà Nội

334 Nguyễn Trợi, Thanh Xuôn

Hà Nới

E-mail:nhdu2001@ yahoo.com

29. Hoòng Th! Thuỳ Dưong

Học viên Cao học

K14 Đại học Su phạm hà Nợi

219 Hoàng Hoa Thám

Ba Đình Hà Nội

E-mail: nnquan2510@yahoo.com

30. Nouyēn Thuỳ Dưong

Đại học Khoa học tụ nhiên

Dại học Quóc gia Hà Nợi

334 Nguyễn Trởi, Thanh Xuân

Hà Nơi

E-mail: vietphuongvn@gmall.com

31. Trưong Th! Thuỳ Dương

Học viên Cao học

K13 Đại học Su Phạm

Hà Nội

32. Dương Tôn Đảm

Đại học Quốc Gia

Thành phố Hồ Chí Minh

525/40 Huỳnh Văn Bánh

Quộn Phú Nhuộn

Thành phó Hớ Chî Minh

33. Chu Th! Hớng Đăng

Dại học Khoa học tụ nhiên

Đại học Quốc gia Hà Nợi

334 Nguyễn Trăi, Thanh Xuân

Hà Nội

34. Đỗ Đình Địch

Khoa Địa lý

Đại học Khoa học tụ nhiên

Đại học Quó́c gia Hà Nội

334 Nguyễn Trãi, Thanh Xuấn

Hà Nôi

E-mail: ddich@yahoo.com

35. Trồn Duy Đlộp

Học viên Cao học

K12, Đại học Vinh

E-mail:duylepdt@yahoo.com

36. Nguyễn Cơng Đióu

Viện Cồng nghệ Thớng tin 


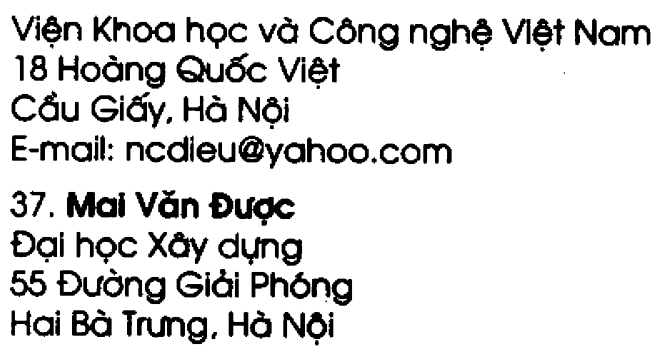

38. Đinh Văn Gắng

Khoa Toán, Đại học Su phạm

Thành phớ Hố Chi Minh

39. Dảo Mạnh Hà

Tổng Cơng ty Hàng không Việt Nam

200 Nguyẻ̉n Son - Gia Lâm Hò Nợi

E-mail: Hadm.pmd@vietnamair.com.vn

40. Hoòng Th! Thu Hò

Học viên Cao học K13

Đại học Su phạm Hà nội

136 Xuân Thuỷ, Cầu Giấy, Hà Nội

41. Phạm Xuân Hà

Đại học Sư phạm Hà Nội

136 Xuân Thuỷ, Cầu Giấy

Hà Nồi

\section{2. Đọ̆ng Thanh Hỏl}

Học viện Phòng khớng Khớng quân

Đường Trường Chinh. Hà Nợi

\section{3. Đăng Văn Hól}

Học vien Cao học

K12, Dai hoc Vinh

E-mail: haidaison1979@yahoo.com

44. Lê Hoàng Hải

Tổng Công ty Hàng không Việt Nam

200 Nguyễn Sơn - Gia Lâm Hà Nộii

E-mail: Hadm.pmd@vietnamair.com.vn

45. Nguyền Hồng Hải

Viện Công nghệ thông tin

Bố Quốc Phòng

34 A Trần Phú, Hà Nội

\section{Nguyēnn Hắc Hải}

Đại học Sư phạm Hà Nôi

136 Xuôn Thuỷ, Cầu Giấy

Hà Nợi

\section{Nguyễn Văn Hál}

Phổ thông trung học
Báo Lộc, Lâm Đồng

44A Trần Khánh Du

Thành phố Đà Lạt

E-mail: langbiang17@yahoo.com

48. Nguyên Văn Hải

Học viên Cao học

K12 Đại học Đà Lạt

E-mail: nguyenhai44a@yahoo.com

49. Phan Thu Hài

Tớng Công ty Dớu khi

Việt Nam

\section{0. Đỗ Văn Hiệp}

Đại học Bách Khoa Hà Nợi

1 Đại Cớ Việt

Hai Bà Trung. Hà Nơ̂i

51. Phạm Đức Hiẹpp

Ko Cử nhân Tài năng

Đại học Khoa học tụ nhiên

Đại học Quốc gia Hà Nội

334 Nguyễn Trãi, Thanh Xuân

Hà Nội

\section{Dưong Naọc Háo}

Trưòng Đại họ SPKT

Thành Phớ Hổ Chí Minh

01 Võ Văn Ngẩn. Thủ Đúc

Thành Phơ Hớ Chí Minh

E-mail: dnhao74@yahoo.com

\section{Phọm Thị Hŏ̀ng}

Đọl học Khoa học tụ nhiên

Đại học Quớc gla Hà Nội

334 Nguyễn Träi, Thanh Xưån

Hà Nội

Email: hangpt@vnu.edu.vn

\section{Vơ Thḷ Hờng}

Học viên Cao hoc

K12, Đại họ Vinh.

E-mall: vohongvan_dhv@yahoo.com

55. Trờn Th! Hoa

Hoc vien Cao hoc

K13 Đại hoc Su pham Hà Nới

136 Xuấn Thuỳ, Cớu Giáy

Hà Nọii

56. Phạm Thị Thu Hoo

Dại học An Giang 
25 Võ Thị Sáu

Thành phó Long Xuyên

Tinh An Giang

E-mail: hoahuong2002_agu@yahoo.com

\section{Vũ Thl Hoà}

Dại hoc Xồy dựng

55 Đường Giái Phóng

Hai Bà Trung, Hà Nợi

58. Vũ Thu Hoài

Đại học Y Hà Nội

59. Bùl Quóc Hoàn

Đai học Khoa học tụ nhiôn

Đại học Quóc gia Hà Nợi

334 Nguyẽnn Trăi, Thanh Xuån

Hà Nối

E-mail: hoanbq@vnu.edu.vn

60. Vương Quân Hoàng

Conng ty EMISCOM

61. Nguyễn Thị Hồng

Học Viện Mật mã

Tåy Mỗ, Tù Liêm Hà Nội

E-mail: hong9480@yahoo.com

\section{Nguyễn Th! Thuý Hớng}

Hoc vién Cao học

KII Viên Toán học

18 Hoảng Quóc Việt

Cởu Giớy, Hà Nội

\section{Nguyễn Văn Huăn}

Trường PTTH Kỳ Lâm

Kỳ Anh, Hà Tình

E-mail: vohongvandhv@yahoo.com

\section{Nguyễn Khánh Hùng}

Học viên Cao học

K13 Đại học Sư phạm Hà Nội

136 Xuân Thuỷ, Cầu Giấy

Hà Nội

65. Phạm Việt Hùng

Đại học Bách Khoa

Thành phơ Hở Chî Minh

888/67/746 Lạc Long Quân

Phường 8, Quân Tân Bình

Thành phố Hồ Chí Minh

E-mail: pvhung@yahoo.com

\section{Trần Lợc Hùng}

Đại học Khoa học Hué
77 Nguyễn Huê. Hué

E-mail: thung@hueuni.edu.vn

67. Vơ Thị Huyớn

Học viên Cao học

K12 Đai hoc Vinh

E-mail: huyenuanhoa@yahoo.com

68. Nguyễn Quang Hưng

Học viên Cao học

K12 Toán, Đại học Vinh

Thành phố Vinh, Nghệ An

E-mail:qhungch12@yahoo.com

69. Nguyên Thị Minh Hung

Khoa Tư nhiên

Trường Cao đắng Su phạm

Hà Tinh

E-mail: vohongvan_dhv@yahoo.com

70. Nguyễn Lan Hương

Viện Chiến lược Phát triển

Bộ Kế hoọh và Đẩu tư

65 Văn Miếu Hà Nội

E-mail:huongn|@dsi.org.vn

71. Phạm Thị Thu Hương

Dại học An Giang

25 Vơ Thị Sáu

Thành phó Long Xuyẽn

Tinh An Giang

E-mail: hoahuong2002_agu@yahoo.com

72. Phan Th! Hương

Đại học Khoa học tụ nhiên

Đai học Quốc gia Hà nội

334 Nguyễn Trăi, Thanh Xuân

Hà Nôi

E-mail: pthuong10000@yahoo.com

73. Trồn Thu Hương

Học viên Cao học

K12 Đai hoc Vinh

E-mai: thuhuongt12@yahoo.com

74. Nguyē̌n Vŏn Hữu

Đại học Khoa học tư nhiên

Đại học Quóc gia Hà Nợi

334 Nguyễn Trăii, Thanh Xuân

Hà Nới

E-mail: nhdu2001@ yahoo.com

75. Nguyỗn Qứ Hỳ

Đại học Khoa học tụ nhiên 
Đại học Quóc gia Hả nội 334 Nguyển Trăl, Thanh Xuån Hò Nội

76. Nguyē̃n Khắc Khanh Khoa khoa hoc co bán Truờng Cao đởng Cộng đóng Bà Rịa - Vũng Tàu 80 Trương Công Định Thành Phó Vũng Tàu Tỉnh Bà Rịa - Vüng Tàu E-mail: trandinhtuong@math.com

\section{Trần Văn Kiên}

Đại học Khoa học tụ nhiên

Đại học Quốc gia Hà nội

334 Nguyễn Trãi, Thanh Xuân

Hà Nôi

E-mail: khienkt@yahoo.com

78. Đoàn Minh Khoa

Đại học Khoa học tự nhiên

Đại học Quớc gia Hà nội

P203. Nhà Eo.

Thanh Xuån Bắc, Hà Nợi

E-mail: minhkhoatb@yahoo.com

\section{Phạm Quang Khoái}

Học viên Cao học

K13 Đại hoc Sư phạm Hà Nọi

136 Xuån Thuỷ, Cổu Giấy

Hà Nốl

E-mail: quangkhoaihd@yahoo.com

\section{Phạm Văn Khánh}

Học Viện Kỹ thuật Quân sự

100 Hoàng Quốc Việt

Cầu Giấy, Hà Nội

81. Trần Quốc Khánh

Học viên Cao học

KII Viện Toán học

18 Hoăng Quóc Việt

Cẩu Giớy, Hà Nội

82. Lê Trung Kiên

Toán K25, Khoa Toán

Trường Đại học Khoa học Huế

77 Nguyễn Hựe. Huế

E-mail: hieukien@hotmail.com

83. Phạm Văn Klồu

Đại học Sư phạm Hà Nợi
136 Xuån Thuỳ, Cắu Giớy Hà Nội

84. Lé Xuấn Lam

Học viện Hành chính Qước gia

85. Nguyển Tuyết Lan

Học viên Cao học

K13 Đọi học Sư phạm Hà Nội

136 Xuỡn Thuỷ, Cầu Giấy

Hà Nội

86. Phan Thi Lan

Đại học khoa học tụ nhiên

Đại học Quóc gia Hà Nợi

334 Nguyẽ̃n Trăi, Thanh Xuấn Hà Nội

87. Nguyễn Thị Chí Linh

Đại học khoa học tụ nhiên

Đại học Quốc gia Hà Nội

334 Nguyễn Trăi, Thanh Xuân

Hà Nội

88. Dặng Th! Thanh Loan

Học viên coa học Toón

K12 Đại học Đà Lạt

E-mail: nguyenhai44a@yahoo.com

89. Phan Th! Loan

Viện Đại học mớ Hà Nội

90. 0 P̂́ Phi Long

Đại học Quán lý kinh doanh

91. Hoàng Việt Long

Khoa Co bán

Đại học Giao thỏng Vộn tải

92. Ngô Hoàng Long

Đại học Su phạm Hà Nội

136 Xuân Thuỷ, Cớu Giớy

Hà Nội

E-mail: vinhxop@yahoo.com

93. Nguyø̄n Thành Long

Ban Hợp tớc Quớc tó

Uỷ ban chúng khoón nhà nước

164 Trồn Quang Khál, Hò̀ Nợi

94. Trồn Văn Long

Đại học Su phạm Hò Nợi

136 Xữn Thuỳ, Cớu Giớy, Hà Nợi

95. Dinh Quang Luru

Viện Toán học 
18 Hoàng Quóc Vlệt

Cắu Gióy, Hà Nội

E-mail: dqluu@math.ac.vn

\section{Lê Thị Xuớn Mai}

Dại học Khoa học tụ nhiên

Đại học Quóc gia

Thành phó Hớ Chi Minh

258/11 Phan Đinh Phùng,

Pl Quộn Phú Nhuận

Thành phố Hồ Chí Minh

Emaii: Itxmai@mathdep.hcmuns.edu.vn

97. Hoàng Đức Mạnh

Đại học kinh tế Quốc dân

Sớ nhà 42 , ngõ 41

Thái Hò. Hà Nội

E-mail: hdmanh2003@yahoo.com

98. Nguȳ̄n Vŏn Mọnh

Đại học Bách khoa Hà Nợi

1 Đại Cơ Việt

Hai Bà Trung. Hà Nọi

99. Đọ̆ng Qưc Minh

Học viên Cao học

KII Viên Toán học

18 Hoàng Quốc Việt

Cớu Giấy, Hà Nội

100. Dương Thanh My

Đọi học khoa học tụ nhiên

Đọi học Quốc gia Hà Nội

334 Nguyễn Trăi, Thanh Xuãn

Hà Nợi

E-mail: duongthanhml@yahoo.com

101. Nguyĕn Th! Mỳ

Học viên Cao học

K13 Đại học Su phạm Hà Nộ

136 Xuốn Thuỳ. Cớu Giớy

Hà Nội

102. Phan lé Na

Đại học Vinh

E-mail:phanlena@yahoo.com

103. Nguyễn Thị Phương Nam

Học viên Cao học

K13 Đại học Su phạm Hà Nọi

136 Xuân Thuỳ. Cớu Giớy

Hà Nợi

104. Trồn Minh Nope

Đại học khoa học tụ nhiên
Dai học Qức gia Hà Nới

334 Nguyễn Trăil, Thanh Xuån

Hà Nợi

E-mail:ngoctm@vnu.edu.vn

\section{Trö́n Anh Nghio}

Dai hoc Vinh

E-mail: trananhnghiadhv@yahoo.com

106. Nguyễn Thị Nguyệt

PTTH Chu Văn An

Kim Mã, Ba Đình, Hà Nội

E-mail: hong9480@yahoo.com

107. Trồn Trọng Nguyên

Đại học Su phạm 2

Thị xã Phúc Yên, Vĩnh Phúc

E-mail: ttnguyenvp@hn.vnn.vn

108. Nguyø్n Hớng Nhung

Học viên Cao học

Dạl học Khoa học tư nhiên

Dại học Qức gia Hà Nộl

334 Nguyễn Trăl, Thanh Xuân

Hà Nôii

E-mail:blackrosenhung@yahoo.com

109. Nguyễn Thị Hồng Nhung

Học viên Cao học

Dai hoc Vinh

Thành phố Vinh, Nghệ An

E-mail: vohongvandhv@yahoo.com

110. Đặng Thị Tó́ Nhu

Dại học Khoa học Hué

77 Nguyễn Huệ, Thành phó Hué

E-mail: dangnhu@yahoo.com

111. Nguyēn Thị Hoòng Oanh

Độ học Đlếu duỡng Nam Định

Tháł Hà. Hà Nợi

E-mall: hoangoangsp 10yahoo.com

112. Vũ Nog̣c Phát

Viện Toón học

Viện KH và Cơng nghệ Việt Nam

18 Hoàng Qức Việt

Cớu Glớy. Hà Nộl

E-mail: vnphot@math.ac.vn

113. Dàm The Phong

Học vien cao học

Ki3 Đại học Su phạm Hà Nội

136 Xuân Thủy, Cợu Giáy

Hà Nộl 
114. Chu Dinh Phú

Công ty Điện toón

và truyển số liệu (VDC)

292 Tóy Sơn. Đống Đa. Hà Nợi

E-mail: phucd@vdc.com.vn

115. Doăn Trờn Phú

Dại học Thuong Mai

Mai Dịch, Từ Liêm, Hà Nợi

E-mail: huyentrang010981@yahoo.com

116. Hố Đăng Phúc

Viện Toán học

18 Hoàng Quớc Việt

Cấu Giớy, Hà Nỡi

E-mail: hdphuc@math.ac.vn

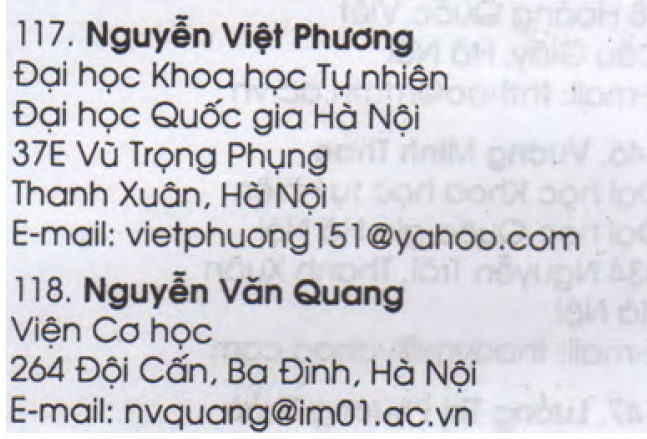

\section{Nguyễn Văn Quảng}

Đại học Vinh

E-mail: nvquang@hotmail.com

120. Nguyễn Nhý Quân

Cao đẳng Điện lực

219 Hoàng Hoa Thám

Ba Đinhn, Hà Nội

E-mail: nnquan2510@yahoo.com

121. Phạm Văn Quốc

Đại học Khoa học tụ nhiên

Đại học Quốc gia Hà Nội

334 Nguyễn Trăi Thanh Xuân

Hà Nội

E-mail: quocpv80@yahoo.com

122. Trờn Đình Quớc

Đại học Khoa học tụ nhiên

Đại học Quó́c gia Hà Nợi

ن34 Nguyễn Trợi Thanh Xuăn

Hà Nợi

123. Lục Nhu Quỳnh

Đại học Khoa học tụ nhiên
Đại học Quóc gia Hà Nợi 334 Nguyên Trăl Thanh Xuấn Hà Nội

124. Nguyễn Hồ Quỳnh

Đại học Bách khoa Hà Nội

1 Đại Cồ Viêt

Hai Bà Trung, Hà Nội

E-mail:hoquynh@hn.vnn.vn

125. Trịnh Nhu Quỳnh

Tó bọ món Toán Tin

Khoa khoa hoc Co bán

Trường Sỹ quan Pháo binh

Son Lợc, Son Tây, Hà Tây

E-mail: tnquynh 112@yahoo.com

126. Đoàn Thái Sơn

Ko Toán Củ nhân Tài năng

Đại học Khoa học tụ nhiên

Đại học Quốc gia Hà Nội

334 Nguyễn Trăi Thanh Xuân

Hà Nội

E-mail: sonk6@ayhoo.com

127. Đỗ Thế Sơn

Học viên Cao học

KI3 Đại học Sư phạm Hà Nợi

136 Xuån Thuỳ. Cớu Gláy

Hà Nội

\section{Lê Hống Sơn}

Cao Đẳng Sư phạm Kỹ Thuật Vinh

Phường Hưng Dũng

Thành phố Vinh, Nghê An

E-mail:Ihsondhv@yahoo.com

129. Nguyễn Lưu Sơn

Đại học Khoa học tụ nhiên

Đọi học Quốc gia Hà Nới

334 Nguyẻn Trăi Thanh Xuån

Hà Nối

E-mail: nluuson@yahoo.com

130. Phạm Văn Sơn

Đại học Mỏ Địa chớt

Đớng Ngạc, Tư Liêm, Hà Nợi

E-mail: sonpv1978@yahoo.com

131. Vũ Hái Sâm

Đại học Khoa học tụ nhiên

Đại học Quóc gia Hà Nợi

334 Nguyễn Trăi Thanh Xuån 
Hà Nội

E-mail: vhsam@yahoo.com

\section{Vơ Văn Tài}

Bợ môn Toán

Khoa khoa học co bán

Đọi học Cồn Tho

E-mail: wtai@ctu.edu.vn

\section{Nguyễn Thê Tâm}

Họ viên Cao học

K12 Đai hoc Vinh

E-mail: tamnhlien@yahoo.com

134. Bùi Thị Thanh

Học viên Cao học

Kll Dai họ Vinh

E-mail: vohongvan_dhv@yahoo.com

\section{Trồn Đăng Thanh}

Đại học Hổng Đúc, Thanh Hoá

\section{Trần Kim Thanh}

Khoc cou bản

Đại học Giao Thông vận tải

sớ 2 Đường D3 Văn Thánh Bắc

137. Hoàng Cẩm Thạch

Đọi học Khoa học tụ nhiên

Đại học Quốc gia Hà Nội

334 Nguyễn Trăi. Thanh Xuån

Hà Nợi

\section{Nguyēn Hoàng Thành}

Viện Cơ học

264 Đội Cấn, Ba Đình, Hà Nội

E-mail: nhthanh2001@yahoo.com

139. Lê Văn Thành

Đại học Vinh

E-mail: Ivthanhvinh@yahoo.com

140. Phan Đúc Thành

Dại học Vinh

\section{Trờn Công Thành}

Học viên Cao học

K11 Dai hoc Vinh

E-mail: vohongvan_dhv@yahoo.com

142. Trờn Văn Thành

Viện Toán học
18 Hoàng Quốc Việt

Cắu Gióyy. Hà Nội

E-mail: tvthanh@math.ac.vn

143. Phạm Thiếu

Đại họ̣c Kinh tế Quốc dân

Phường Đồng Tâm

Hai Bà Trung, Hà Nội

144. Nguyễn Huy Thao

Học viên Cao học

K12 Đại học Vinh

E-mail: thaonguyenhuy@yahoo.com

145. Trồn Hùng Thao

Vlện Toán học

18 Hoàng Quốc Việt

Cấu Giáy, Hà Nội

E-mail: ththao@math.ac.vn

146. Vurong Minh Thao

Đại học Khoa học tụ nhiên

Đại học Quốc gia Hà Nội

334 Nguyễn Träi, Thanh Xuân

Hà Nội

E-mail: thaovm@yahoo.com

147. Lương Thị Phương Thào

Đại học Đà Lạt

04 Huỳnh Thúc Kháng

Thành phố Đà Lạt, Lâm Đồng

E-mail: phuongthaod125@yahoo.com

148. Phạm Hoàng Ngọc Thảo

Đại học Đà Lạt

04 Huỳnh Thúc Kháng

Thảnh phố Đà Lạt. Lâm Đồng

E-mail: phuongthaodl25@yahoo.com

149. Đặng Hùng Thắng

Đọi học Khoa học tụ nhiên

Đọi học Quốc gia Hà Nội

334 Nguyễn Trãi, Thanh Xuân

Hà Nội

E-mail: hungthang@hnn.vn.vn

150. Nguyên Quరcc Thớng

Truờng PTHH Phúc Trạch

Hương Khê., Hò Tinh

E-mail:vohongvandhv@yahoo.com

151. Tạ Văn Thắng

Dại học Khoa học tụ nhién

Đại học Quó́c gia Há Nội 
334 Nguyẽ̃n Trăi, Thanh Xuấn Hà Nội

\section{Nguyễn Thịnh}

Dại học Khoa học tư nhiên

Đại học Quốc gia Hà Nợi

334 Nguyễn Trăi, Thanh Xuân

Hà Nội

E-mail: nguyenthinh@vnu.edu.vn

153. Nguyĕn Tuắn Thlộn

Đọi học Bách Khoa Hà Nội

1 Đài Cổ Việt, Hà Nơoi

E-mail: tuanthienbk@yahoo.com

154. Trương Hoàng Thông

Học Viện Hậu cần

Phường Ngọc Thuy

Quận Long Biên, Hà Nội

155. Nguyễn Văn Thu

Viện Toán học

18 Hoàng Quốc Việt

Cầu Giấy, Hà Nội

E-mail: nvthu@math.ac.vn

156. Đỗ Ngọc Thuỷ

Đại học Su phạm Hải Phòng

157. Nguyễn Thu Thuỷ

Đai học Su Pham Hà Nôi

136 Xuân Thuỷ, Cầu Giấy

Hà Nôi

E-mail:vinhxop@yahoo.com

158. Lê Thị Thanh Thuỳ

Học Viên Cao học

Đại học Khoa học tụ nhiên

Đại học Quốc gia Hà Nội

Số nhà 77 ngách 41

Ngõ Thịnh Quang - Tây Sơn

Đống Đa Hà Nội

E-mail: lethanhthuy81@yahoo.com

159. Dào Thị Thuộn

Học vién Cao học

Đại học Sư Phạm Hò Nội

136 Xuân Thuỳ, Cờu Giốy

Hà Nội

160. Dinh Ngọc Thuồn

Học viên Cao học

Viện Toán học
18 Hoàng Quóc Việt

Cầu Giấy, Hà Nội

E-mail: dnthuan02@yahoo.com

161. Phan Viết Thu

Đại học Khoa học Tụ nhiên

Đại học Quốc gia Hà Nội

334 Nguyễn Trāi, Thanh Xuân

Hà Nội

162. Ngô Văn Thứ

Đại học Kinh tế Quốc dân

Phường Đồng Tâm

Hai Bà Trung, Hà Nội

163. Khuất Việt Thường

Học Viện Biên Phòng

164. Nguyễn Duy Tiến

Đại học Khoa học tư nhiên

Đại học Quốc gia Hà Nội

334 Nguyễn Trãi, Thanh Xuân

Hà Nôi

E-mail: duytien@netnam.org.vn

165. Nguyễn Hữu Tiến

Đại học Bách khoa Hà Nội

1 Đại Cổ Viêt

Hai Bà Trung, Hà Nội.

\section{Nguyẽ̃n Văn Tinh}

Học viên Cao học

Đại học Khoa học tư nhiên

Đại học Quó́c gia Hà Nới

334 Nguyěnn Trăi, Thanh Xuân

Hà Nợi

167. Trần Minh Toàn

Đại học Khoa học tụ nhiên

Đại học Quốc gia Hà Nội

334 Nguyễn Trăil, Thanh Xuân

Hà Nội

\section{Vū Huyền Trang}

Bợ mơn Toán

Dại học Thuong Mại

Mai Dịch, Tư Liêm, Hà Nôi

E-mail: huyentrang010981@yahoo.com

169. Độu Anh Tư̆́n

Học viên Cao hoc

K12 Đai hoc Vinh

Thành phố Ving, Nghệ An

E-mail: cdtuancd@yahoo.com 
170. Đinh Thanh Tuắn Khoo CNTT Khu vulc I. Đại học Khoa học Tụ nhiên Đại học Quర́c gia Thành phó HCM 227 Nguyễn Vắn Cù. Quộn 5 Thành phớ Hồ Chí Minh

\section{Nguyễn Anh Tuăn}

Bộ môn Phương pháp giảng dạy Đại học Su phạm Hà Nội 136 Xuân Thuỷ Cớu Giáýy, Hà Nợi

172. Nguyễn Quốc Tuấn
Học viện Kỹ thuật Quân sụ
100 Hoăng Quốc Việt, Cẩu Giấy, Hà Nội
nguyenquoctuan 1481 @yahoo.com

\section{Trờn Mạnh Tướn}

Viện Khoa học và Công nghệ Việt Nam 18 Hoàng Quốc Việt

Cổu Gióyy, Hà Nợi

E-mail: tmtuan@vast.ac.vn

\section{Trần Thanh Tuấn}

Đại học Khoa học tự nhiên

Đại học Quốc gia Hà Nội

334 Nguyễn Trãi, Thanh Xuân Hà Nội

\section{5. Đào Quang Tuyón}

Viện Toán học

Viện Khoa học và Công nghệ Việt Nam 18 Hoàng Quốc Việt

Cởu Giấy, Hà Nội

E-mail: dqtuyen@math.ac.vn

176. Dương Thị Tuyền

Bợ môn Toán - Khoa Khoa học

Trường đại học Cốn Tho

E-mail: dttuyen@ctu.edu.vn

\section{Nguyø̄n Thị Tú}

Cóng ty FPT

Láng Hạ, Hà Nợi

E-mail: nttu@fpt.vn

\section{Köng Ty}

Dại học Bách khoa Hà Nội

1 Đài Cớ Việt, Hà Nợi

\section{Hoàng Thanh Tùng}

Đại học Khoa học tụ nhiên

Đại học Quóc gia Hà Nội
334 Nguyě̃n Trăii, Thanh Xuån Hà Nợi

180. Phạm Vił̌t Thanh Tùng

Học viên Cao học

K14 Đại học Su phạm Hà Nội

136 Xuân Thuỷ, Cớu Giớy

Hà Nội

\section{Trần Đình Tướng \\ Khoa khoa học cơ bán \\ Trường Cao đẳng Cộng đồng \\ Bà Rịa - Vũng Tàu \\ 80 Trương Công Định \\ Thành Phố Vũng Tàu \\ Tỉnh Bà Rịa - Vũng Tàu \\ E-mail: trandinhtuong@math.com}

182. Cồm Hoải Vắn

Đọi học Khoa học Tư nhiên

Đại học Qức gia Hà Nợi

334 Nguyễn Trăi, Thanh Xuân Hà Nội.

183. Võ Thị Hổng Vân

Học viên Cao học

Đại học Vinh

Thành phố Vinh, Nghệ An

E-mail:vohongvan_dhv@yahoo.com

184. Nguyỗn Bác Văn

Đại học Khoa học Tụ nhiên

Đại học Quóc gia Thành phó HCM

227 Nguyển Vắn Cừ, Quộn 5

Thảnh phớ Hờ Chí Minh

nbvan@mathdep.hcmuns.edu.vn

185. Trần Quang Vinh

Đại học Su phạm Hà Nội

136 Xuân Thuỷ, Cầu Giấy, Hà Nội

E-mail:vinhxop@yahoo.com

186. Vơ Văn Vinh

Đại học Bách khoa Hà Nợi

Só 1 Đại Cớ Việt

Hai Bà Trung, Hà Nợi

187. Truơng Chi Vinh

Hiệp hội ché biến và xuát khắu

Thuỷ sán VASEP

10 Nguyễn Co̊ng Hoan

Ba Einh, Hà Nợi

E-mail: vinhtt@vasep.com.vn 
188. Vũ Tión Viẹt

Đại học An ninh nhân dản

Thị xỡ Hả Đớng. Hà Tấy

189. Bùi Quang Vũ

Khoa Toán, Đại học Khoa học Huế

77 Nguyễn Huệ, Thành phố Huế

E-mail:bqvu288@yahoo.com

190. Lé Anh Vũ

Department of Computer Science

ELTE University, Hungary

E-mail: leanhvu@inf.elte.hu

191. Nguyēn Phương Vũ

Sơ Gláo dục vă Đảo tạo Hà Nội

192. Vū Viêt Yên

Dại học Su phạm Hà Nội

136 Xuấn Thuỳ, Cắu Giớy, Hà Nợi 


\section{Chỉ số}

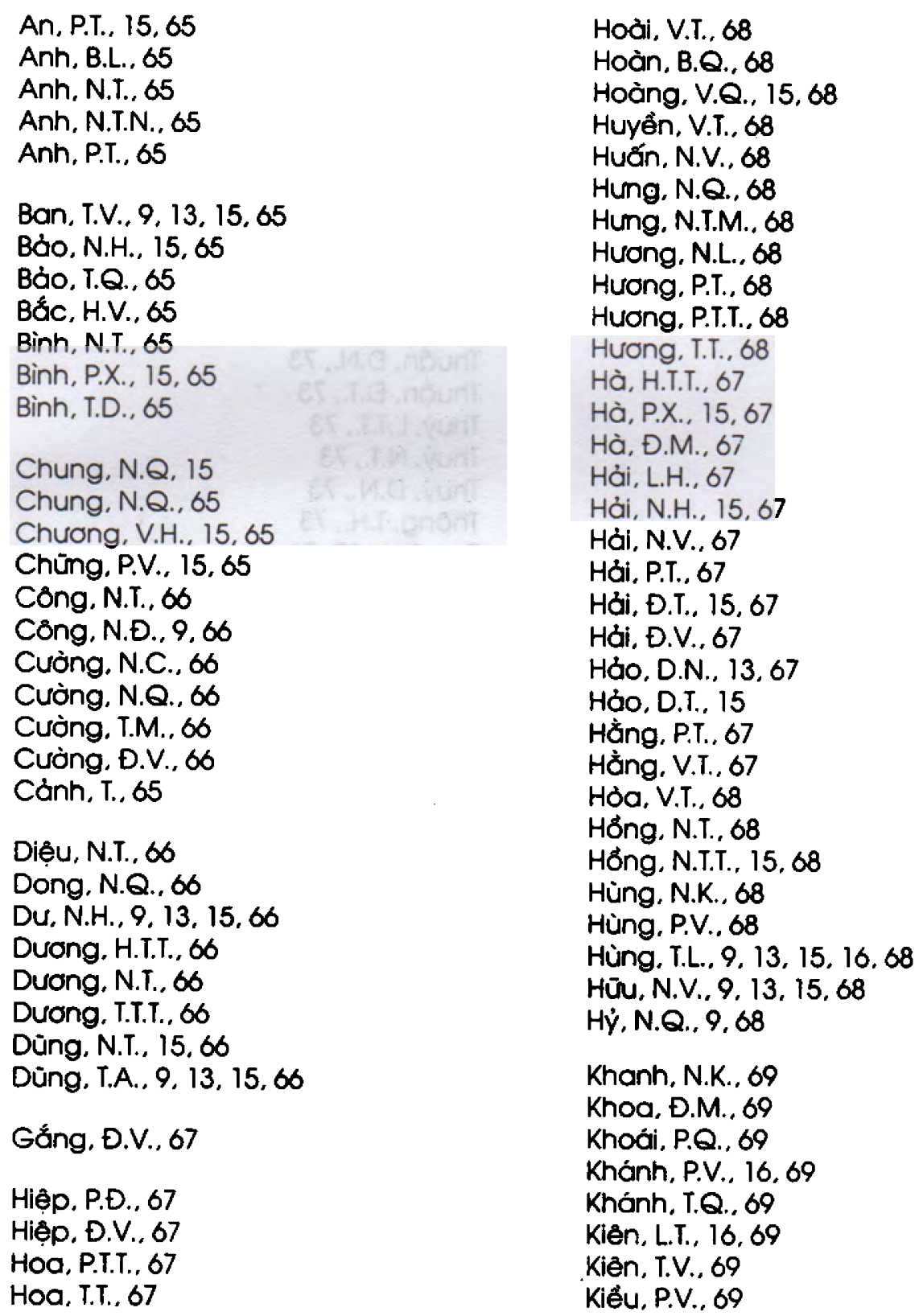


Lam, L.X. 69

Lan, P.T, 69

Linh, N.T.C., 69

Loan, P.T., 69

Loan, Đ.T.T. 69

Long, H... 69

Long, N.H. , 69

Long. N.T., 13, 16, 69

Long. T.V., 69

Long, Đ.P., 69

LuU, $0 . Q ., 9,13,15,16,69$

Mai, L.T.X., 70

Mai, L.TX., 16

Minh, 0. Q., 70

My, D.T., 70

Mạnh. H.M., 70

Mạnh, H.Đ. 16

Mạnh, N.V., 70

Mỳ. N.T., 16, 70

Na, P.L., 15, 16, 70

Nam. N.T.P., 70

Nghĩa, T.A., 70

Nguyên, T.T., 16, 70

Nguyệt, N.T., 70

Ngqc, T.M. 15

NgQc, T.M. , 70

Nhung, N.T. , 70

Nhung, N.T.H., 70

Nhung, T.V., 9

Nhu, Đ.T.T., 16, 70

Oanh, N.T.H., 70

Phong, D.T., 70

Phuoong, N.V., 71

Phát, V.N., 70

Phú, C.Đ., 71

Phú, D.T., 16.71

Phúc, H.Đ. 9, 13, 16, 17, 71

Quang, N.V., 71

Qư̊n. N.N., 71

Quáng. N.V., 9, 13, 16. 71

Quóc. P.V., 71

Quốc. T.Đ.. 71

Quy, T.D., 9

Quỳnh, L.N., 71

Quỳnh, N.H., 16.71
Quỳnh, T.N., 71

Sâm, V.H., 71

Son, L.H., 71

Son, N.L., 71

Son, P.V., 71

Son, Đ.T., 16. 71

Thanh, B.T., 72

Thanh, T.K., 72

Thanh, T.Đ., 72

Thao, N.H., 72

Thao, T.H., 9, 14--16, 72

Thao, V.M., 72

Thiếu, P.T., 72

Thiện, N.T., 73

Thu, N.V., 9, 14, 17, 73

Thuờn, Đ.N.. 73

Thuỡn. D.T., 73

Thuỳ, L.T.T., 73

Thuỳ, N.T., 73

Thuy', Đ.N., 73

Thông. T.H., 73

Thu, P.V., 17, 73

Thường, K.V., 73

Thành, L.V., 16, 72

Thành, N.H., 72

Thành, P.D, 16

Thành, P.Đ., 13, 72

Thành, T.C., 72

Thành, T.V., 9,72

Thdo. L.T.P., 72

Thdo. P.H.N., 72

Thanh, H.C., 72

Thắng, N.Q., 72

Thắng, T.V., 72

Thắng, Đ.Н., 9, 14, 16. 72

Thinh, N., 16, 73

Thú, N.V., 73

N.D., 9

Tién, N.D., 14, 17, 73

Tién, N.H., 73

Toàn, T.M., 73

Trang. V.H., 16, 73

Tuyến. D.T., 74

Tuyến, D.Q., 17

Tuyến, Đ.Q., 9. 14, 74

Tuó́n, N.A., 74

Tuán, N.Q.. 74

Tuắn. T.M., 9. 17, 74 
Tư์́n, T.T., 74

Tuốn, Đ.A., 73

Tuớn, Đ.T., 74

Tấm. N.T., 72

Tương, T.Đ.. 74

Tài, V.V., 72

Tinh, N.V., 73

Tùng. H.T., 74

Tùng. P.V.T., 74

Tú, N.T., 74

Tụ, K., 14, 17.74

Vinh, T.Q., 74

Vinh, V.V., 74

Viêt, V.T., 75

Vờn, N.B., 9, 14, 17, 74

Vån, C.H., 74

Vån, V.T.H., 74

Vinh, T.C., 74

Vũ, B.Q., 17, 75

Vũ, L.A., 16, 75

Vũ, N.P., 75

Yên, V.V., 9, 14, 17, 75

Điễu, N.C., 15, 66

Điệ̂, T.D. 66

Đăng. C.T.H., 66

Đưọc, M.V., 67

Đám. D.T., 9. 13, 15, 66

Ðịch, Ð.Ð., 66

ánh, T.N. 65 